\title{
Bartomeu de Tresbens, metge i astròleg de Pere el Cerimoniós: aproximació biogràfica i diplomatari
}

\author{
Carmel Ferragud \\ Sebastià Giralt
}

\author{
Institut Interuniversitari López Piñero, Universitat de València I \\ Universitat Autònoma de Barcelona \\ $\frac{\text { https://orcid.org/oooO-OOO2-9756-9257 }}{\underline{\text { hebastia.Giralt@uab.cat }}}$
}

Received 04/o2/2OI9; accepted o5/o3/2OI9

DOI: https://doi.org/IO.7203/MCLM.6.I3906

Bartomeu de Tresbens, physician and astrologer to Pere the Ceremonious: biographical attempt and documents

Abstract

A biographical approach to Bertomeu de Tresbens, a physician and astrologer who worked for King Pere el Cerimoniós of Aragon and for his son infant Joan, later known as Joan I el Caçador. This biography is built on a thorough reseach based on all documentation on him found in archives - principally in the Archive of the Crown of Aragon-, as well as on the information contained in all his astrology works. We place Tresbens in his Occitan origin and in the economic, political and social contexts of the time when he had been documented in territories of the Crown of Aragon. Thus, the man behind the most important Catalan oeuvre on astrology is brought to light. We have studied particularly his career regarding his relationship with the monarchy and with the town of Cervera, whose local government planned to employ him as a physician. Finally, we present an original edition of all documentation found in archives regarding Tresbens used in this paper.

\section{KEYWORDS}

Medieval astrology; medieval medicine; contracts; royal household; Crown of Aragon; medical licensing examinators; Bartomeu de Tresbens; Pere el Cerimoniós; Joan I el Caçador; fourteenth century; Iberian Peninsula

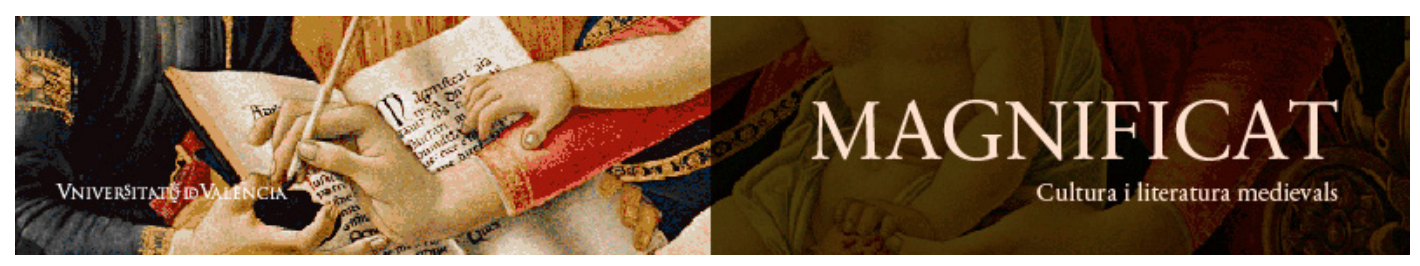

Magnificat Cultura i Literatura Medievals 6, 2019, II3-г63. http://ojs.uv.es/index.php/MCLM

ISSN $2386-8295$ 
RESUM

Aproximació biogràfica a Bartomeu de Tresbens, físic i astròleg al servei del rei Pere el Cerimoniós i del seu fill l'infant Joan, futur Joan I el Caçador. Ho fem a partir del conjunt de la documentació sobre aquest personatge que fins ara ha estat descoberta als arxius, fonamentalment a l'Arxiu de la Corona d'Aragó, i també a partir de les notícies que apareixen en el conjunt de les seves obres sobre astrologia. Hem situat Tresbens en els seus orígens occitans, així com en el context de les activitats econòmiques, polítiques i socials durant el temps que el tenim documentat en terres de la Corona d'Aragó, mostrant l'home que hi ha al darrere de la més important obra astrològica en català. Particularment estudiem la seva trajectòria a partir de la relació que va mantenir amb la monarquia i també amb el municipi de Cervera, el govern municipal del qual va pretendre contractar-lo com a metge. Finalment, oferim l'edició original de tota la documentació arxivística sobre Tresbens que hem utilitzat en el present treball a manera de diplomatari.

PARAULES CLAU

Astrologia medieval; medicina medieval; contracte; casa reial; Corona d'Aragó; tribunals examinadors de metges; Bartomeu de Tresbens; Pere el Cerimoniós; Joan I el Caçador; segle XIV; Península Ibèrica

Carmel Ferragud i Sebastià Giralt. 20I9. 'Bartomeu de Tresbens, metge i astròleg de Pere el Cerimoniós: aproximació biogràfica i diplomatari', Magnificat Cultura i Literatura Medievals, 6 : II3-I63 (c) Br

Aquest estudi s'ha realitzat en el marc dels següents projectes: " Narpan II/VerMed - "Vernacular Science in the Crown of Aragon and Its Wider Romance Context (I3th - I6th Centuries)", MINECO, Ref. PGC2OI8-o954I7-B-C6-4, 2OI9-2O2I (Carmel Ferragud); "Corpus digital de Arnau de Vilanova: filosofia y ciencia en la Corona de Aragón (siglos XIII-XIV) (ArnauDB)", MINECO, FFI2OI4-53O5O-C5-2-P (Sebastià Giralt); Grup de Recerca Consolidat de Cultura i Literatura a la Baixa Edat Mitjana 20I7 SGR I42.

\section{TAULA DE CONTINGUTS}

I Introducció: fragments d'una biografia - II5

2 Del comtat de Foix a Barcelona: els orígens i la família de Bartomeu de Tresbens - II5

3 Al servei de la Corona - II

3.I Assalariat de la casa reial - II8

3.2 Astròleg del rei - 120

$3 \cdot 3$ Físic de la casa reial - $\mathrm{I} 25$

4 Regulació dels practicants de la medicina - I26

5 Amb bon ull per als negocis - I3O

6 La temptació de Cervera - I32

${ }_{7}$ Conclusions: una carrera a l'ombra del poder - I35

8 Agraïments - I35

${ }_{9}$ Obres citades - 136

9.I Abreviatures utilitzades - I39

Io Apèndix: Diplomatari. Documentació conservada sobre Bartomeu de Tresbens - I40 IO.I Criteris d'edició - I40 


\section{ə*⿻}

\section{Introducció: fragments d'una biografia}

L

figura i l'obra de Bartomeu de Tresbens no ha estat estudiada, al nostre parer, amb la profunditat que es mereixen la seva contribució a la literatura tècnica en català ni el seu paper en el marc de l'impuls que Pere el Cerimoniós va donar a la ciència de les estrelles, en part perquè els investigadors han donat prioritat a l'estudi de les obres astronòmiques davant les astrològiques, pertanyents a un saber modernament desprestigiat. Fins fa ben poc només se n'havia editat el Llibre de nativitats (Vernet-Romano 1957-1958) i s'havien donat a conèixer alguns dels documents referents al personatge en publicacions esparses. Tanmateix, darrerament s'ha reprès en diversos articles l'estudi tant de la seva obra com de la documentació sobre la seva vida i la seva carrera professional (Ferragud 2OI8; Giralt 2OI7; Giralt 2OI8; Giralt 2OI8b; Cifuentes 2OI2-2OI8: nomizI). D’aquesta nova aproximació sorgeix un metge prestigiós i sobretot l'autor de l'obra astrològica més destacada en una llengua vernacular en l'Europa llatina medieval, de la qual resten quatre tractats que donen una visió força completa dels diversos aspectes de l'astrologia judiciària: el Llibre de les nativitats, el Tractat de les interrogacions, el Tractat de les eleccions i el Libel d'investigació de tresors.

A partir dels trenta-vuit documents coneguts relacionats amb Tresbens, datats entre març de I359 i abril de 1375 i procedents de diversos arxius, però sobretot de l'Arxiu de la Corona d'Aragó (ACA), majoritàriament inèdits, tractem aquí de desenvolupar la seva trajectòria biogràfica. Finalment, els oferim transcrits en apèndix en la seva totalitat. A aquests documents anirem remetent al llarg de l'estudi, indicant-ne el número de referència entre parèntesis. Ara bé, no solament partim de les informacions proporcionades per la documentació, sinó també de les seves obres, que ofereixen dades gens negligibles.

Igual que sobre tants altres personatges medievals, les notícies que tenim sobre Tresbens són fragmentàries i parcials, i només ens deixen entreveure alguns aspectes de la seva vida i de la seva carrera, que aquí intentem contextualitzar. En efecte, molts dels documents que publiquem ens permeten anar més enllà del personatge concret i tocar certes qüestions més àmplies del seu temps i del seu entorn, com el paper de l'astrologia al servei de la monarquia, l'atenció mèdica a la família reial, la regulació per part de la Corona de la pràctica mèdica, la contractació municipal de metges, $o$ certes activitats econòmiques desenvolupades per ells.

\section{Del comtat de Foix a Barcelona: els orígens i la família de Bartomeu de Tresbens}

$\mathrm{H}$ ins l'havia reivindicat com a metge valencià després d'afegir pel seu compte el gentilici “valentí" a un document de l'ACA que va transcriure (doc. 3I) (Ferragud 20I8). Alguns estudiosos posteriors es van fer ressò d'aquesta infundada procedència valenciana. En realitat, la documentació conservada no proporciona cap dada evident que permeti esbrinar d'on provenia Tresbens, tot i que s'hi poden trobar alguns indicis si es llegeix amb l'orientació adient. En canvi, en la seva obra l'astròleg va deixant puntualment algunes dades sobre la seva vida. Gràcies a aquestes engrunes biogràfiques, la recent edició del seu Libel d'investigació de tresors ha posat sobre la pista que els orígens de Tresbens s'han de buscar cap al nord, més enllà de la Corona d'Aragó (Giralt 2OI8b). En efecte, en aquest tractat l'autor recorda que Gaston de Lévis, senyor de Leran, va posar a prova en dues 
ocasions la capacitat endevinatòria de Tresbens: ${ }^{\mathrm{I}}$ en una d'elles l'astròleg va trobar unes grans canonades de coure barrejat amb plom; en una altra va trobar un objecte que s'havia perdut en l’hostal del mateix Gaston. Els senyors de Leran pertanyien a la família noble francesa de Lévis, que s'havia estès pel Llenguadoc arran de la croada albigesa, i hi havia esdevingut poderosa. Cronològicament, és més probable que Tresbens es refereixi a Gaston I de Lévis, mort el ı347, que al seu fill Gaston II, del qual consta que va néixer al voltant de I339 i va fer testament el I383 (Martin 2007: 83). Resulta versemblant situar en aquesta mateixa època una altra de les experiències que recorda: quan va retrobar els seus llibres, que la seva muller havia amagat a la Bastida de Bosinhac. Aquest petit poble, anomenat La Bastide-de-Bousignac en francès, està ubicat a nou quilòmetres al nord de Leran i a quatre al sud de Mirapeis. El fet que les tres experiències que rememora l'autor d'aquest opuscle se situïn en un espai geogràfic determinat fa pensar que hi va viure durant un temps més aviat llarg.

La residència de Tresbens a Leran dona un nou sentit a la relació documentada de Tresbens amb el comtat de Foix, la capital del qual es troba a 30 quilòmetres a l'oest de Leran. Consta que el I372 el rei Pere va atorgar un salconduit al seu metge i astròleg i a un soci mercader de Pàmias, ciutat del comtat de Foix, juntament amb el seu fill, permetent-los circular i comerciar amb plena llibertat pels regnes de la Corona d'Aragó (doc. I2). Precisament a 7 quilòmetres al nord-oest de Foix hi ha un llogaret anomenat Tresbens, que podem presumir que és la localitat natal de Bartomeu. Sota aquesta llum s'entén la presència d'occitanismes i gal-licismes detectats en el Libel d'investigació de tresors que és esperable retrobar en les altres obres transmeses pel manuscrit XXI de la Biblioteca Lambert Mata de Ripoll: el Llibre de les nativitats, el Tractat de les interrogacions i el Tractat de les eleccions-, atès que es poden interpretar com les restes d'un català escrit per un occitanoparlant que han sobreviscut al procés de còpia. Així mateix, es comprèn que necessités un salconduit del governador del Rosselló i la Cerdanya per enviar algú a França a buscar llibres i altres béns que li pertanyien (doc. 27). Devien ser propietats que encara conservava a la senyoria de Leran o al comtat de Foix. Finalment, un altre vincle occità serien els seus estudis a la Facultat de Medicina de Montpeller, una de les més prestigioses d'aquella època, segons es desprèn del fet que una recepta sota el seu nom aparegui en una Summa medicine, una compilació falsament atribuïda a Arnau de Vilanova però en realitat potser elaborada per Hug de Montpeller a partir d'autors majoritàriament relacionats amb la Universitat de Montpeller (Giralt 20ı8; Rosa 2000: 592). A Montpeller, doncs, degué obtenir els títols de mestre en arts i en medicina que sovint acompanyen el seu nom en la documentació.

Tots aquests indicis, presos en el seu conjunt, ens permeten imaginar una trajectòria versemblant: originari de Tresbens, al comtat de Foix, degué estudiar a Montpeller. Després, durant uns anys, que probablement hem de situar a la dècada dels 40 del segle XIV, va residir a la regió de Mirapeis, on degué estar al servei de Gaston de Lévis, senyor de Leran -podem suposar que com a metge i astròleg.

Potser va ser arran de la mort de Gaston de Lévis I el I347, si n’era aquest el protector i no el seu fill, quan Tresbens es va decidir a buscar un nou horitzó professional en un entorn urbà al sud dels Pirineus. En efecte, hi ha una sòlida base documental per afirmar que Tresbens es va establir a Barcelona: el document més antic conegut fa constar la seva participació el I359 en un tribunal mèdic en aquesta ciutat al costat d'altres metges destacats, i podria indicar que havia adquirit prestigi en la professió i que potser ja hi estava arrelat (doc.I); entre juliol i octubre del I372, el Consell municipal de Cervera negocia amb ell a Barcelona per persuadir-lo d'instal-lar-se a la vila

I. El manuscrit que conserva aquest tractat (Ripoll, Biblioteca Lambert Mata, XXI, f. I7IV), diu "lo senyor de la era, mossèn Gastó de Lenis", però s’ha de corregir per "lo senyor de Lerà, mossèn Gastó de Lévis" (Giralt 20I8b). 
(doc. I3); el primogènit Joan fa anar l'astròleg des de Barcelona, on es troba, a València el I373 (doc. I8); i el I375 consta el seu domicili a Barcelona (doc. 38 ). Possiblement va instal-lar-s'hi mogut per l'esperança de donar una empenta a la seva carrera en una de les ciutats més importants dels territoris propers, amb dinamisme econòmic i presència del poder polític. En efecte, el trasllat li va permetre coronar les seves aspiracions professionals quan va entrar al servei de la monarquia catalana a partir de i36o. De tota manera, resulta sorprenent que si, com sembla, Tresbens va tenir residència permanent a Barcelona durant tot el temps que va viure a la Corona d'Aragó, no n’hagi quedat ni un sol reflex en els protocols notarials que es conserven als diferents arxius de la ciutat. ${ }^{2}$

Hem vist, doncs, que de l'obra de Tresbens es poden extreure certes dades personals que no consten en la documentació. També hi trobem algunes al·lusions a la seva família. Així, en el Libel d'investigació de tresors s'esmenta l'esposa (Giralt 20I8b). A partir del capítol I8 del Llibre de les nativitats sabem que va tenir un fill als 47 anys, sense que puguem estar segurs si era de la mateixa muller o d'una altra, atès que utilitza la nativitat del seu propi fill per saber la durada de la vida d'ell mateix, a partir de la qual esbrina que viurà fins els 77 anys -sumant els 30 anys de vida que dona el càlcul als 47 que tenia quan va néixer el seu fill (Vernet-Romano I957-I958: I, I3O-I3I). Si tenim en compte la hipòtesi exposada més endavant que el Llibre de les nativitats, aparentment la més antiga de les seves obres astrològiques conservades, va ser redactat poc després de I363, podríem situar el seu naixement cap a I3I7.

\section{Al servei de la Corona}

$\mathrm{T}$ renta-quatre de les trenta-vuit notícies documentals conservades sobre Bartomeu de Tresbens procedeixen de la Cancelleria reial, i ens donen un marc cronològic d'una quinzena d'anys del servei que va prestar a la Corona -com a mínim des del maig de i36o fins a l'abril de I375, quan sembla que es va acabar bruscament-, malgrat que no sabem si va ser continu. Un bon nombre d'aquest conjunt arxivístic el mostra en el doble perfil de metge i astròleg al servei de la família reial, que és el més habitual entre els astròlegs professionals dels segles XIV i XV (Boudet 2006: 295-325). Tot i així, el títol amb què és designat el seu càrrec oficial a la documentació cancelleresca és el de metge o físic de casa del rei, mai el d'astròleg. En canvi, en les seves obres -astrològiques- es defineix no tan sols com a metge del rei sinó també com a expert en física i filosofia, ${ }^{3}$ així com a "pobre letrat e humil sercador e servidor de veritat dels térmens de philosophia, de medecina e de astrologia" (Giralt 20I8b). Com no és infreqüent, però, aquesta doble dedicació de Tresbens sembla independent l'una de l'altra, atès que no s'observa cap orientació mèdica en la seva obra astrològica conservada, sinó que més aviat està esbiaixada cap a les necessitats del poder polític. Tanmateix, això no vol dir que no emprés recursos astrològics en la seva pràctica mèdica, com era freqüent.

Al llarg de la documentació observem que la relació -documentada a partir de I369- de Tresbens amb el jove primogènit Joan, duc de Girona i futur rei d'Aragó, va esdevenint més estreta que amb Pere el Cerimoniós. L'ascendència que sembla tenir sobre Joan és coherent amb el fort interès que mostra aquest per consultar astròlegs, tant abans com després de succeir el seu pare.

2. Carmel Ferragud ha buidat tots els protocols dels arxius de Barcelona pertanyents a l'època en què tenim documentat el personatge (Arxiu Històric de la Ciutat, Arxiu Històric de Protocols i Arxiu Capitular de la Catedral) sense obtenir-ne cap resultat. Tampoc se l'ha pogut localitzar en els protocols notarials saragossans.

3. "Bartholomeu de Tresbens, metge seu, en la part de phísica e en aquesta matexa expert e de philosofia", al prefaci del Llibre de nativitats, segons el manuscrit Ripoll, Biblioteca Lambert Mata XXI, f. Ir, que dona una lliçó millor que el còdex de París en què es basa l'edició de Vernet-Romano (I957-I958: 39-40). 


\section{I Assalariat de la casa reial}

El marc que va regular la presència dels metges, físics o cirurgians, en la cort al servei del monarca i la seva família, fou el de les Ordinacions de la cort (Gimeno-Gozalbo-Trenchs 20o9: 97-98). D’acord amb aquesta reglamentació, establerta per Pere el Cerimoniós el I344 i inspirada en les Leges palatine de Jaume III de Mallorca, la cort hauria de comptar permanentment amb la supervisió de dos físics a l'atenció particular del rei, que "diligentment insisten per la conservació de nostra salut e a Nós parlen e diguen sens dubte que proceesquam e usem d'aquelles coses que seran a nostra salut profitoses", i naturalment fessin evitar les nocives (Gimeno-Gozalbo-Trenchs 20o9: 97). També se’ls exigia atendre els domèstics i familiars del rei quan se’ls reclamés. Un dels físics hauria de dormir prop de les estances on descansaven el monarca i la seva esposa i fills, per tal d'acudir-hi ràpidament en cas que fos necessari. Aquests físics haurien d'observar cada matí l'orina del monarca, per veure si s'hi detectava alguna alteració que exigís un tractament adequat. Amb això no feien sinó seguir un procediment rutinari, la uroscòpia, establert pel galenisme com a instrument diagnòstic i pronòstic (Moulinier-Brogi 2OI2).

El físic controlava directament els aliments que ingeria el rei, per vetllar que no consumís aliments nocius per a la seva salut. Aquest, el del consum dels aliments, era un punt fonamental dins el regiment de sanitat que havia de mantenir algú de l'entitat del monarca, ja que l'alimentació es reconeixia com un dels elements essencials per preservar-se de la malaltia (Gil I996: I83-I84). Encara, si el rei era enverinat, el físic havia d'actuar ràpidament amb l'antídot pertinent. Certament, la por que algun tòxic fos introduït entre els aliments, particularment l'arsènic, feia que els monarques medievals prengueren tot tipus de precaucions (Collard 2003: 83-85; McVaugh I993: I57-I5).

També es va marcar jeràrquicament que el metge amb més graus acadèmics precedís l'altre, i si eren del mateix rang seria aquell més honorable el que acudís en primera instància. Fet i fet, això no fa més que evidenciar com formació i promoció social actuaven unides amb gran claredat en el món dels practicants de la medicina, i més que enlloc entre els situats a l'elit. Finalment, cal dir que el físic principal tenia sota les seves ordres l'apotecari, i també els altres físics, que havien de tastar personalment els medicaments abans que fossin donats al rei; els físics, per la seva banda, com també els cirurgians -amb una presència menys freqüent, i més pensada per acompanyar-los en temps de guerra-, estaven sotmesos als camarlencs.

Com es pot observar, doncs, la proximitat dels metges de confiança era molt gran en la vida quotidiana de la cort, i la influència que aquests podien exercir sobre les persones del rei i les dels seus pròxims no era gens negligible. En realitat, un monarca com Pere el Cerimoniós tenia al seu servei una llarga nòmina de físics i cirurgians distingits com a "domèstics" o "familiars" reials, que havien rebut aquest privilegi malgrat trobar-se dispersos per tots els territoris de la Corona, i als quals podia recórrer el monarca puntualment quan es movia amb la cort, com era habitual. ${ }^{4}$ De fet, el personal mèdic al servei de la monarquia havia d'estar disposat a viatjar sovint, perquè en qualsevol moment podia ser reclamat. Aquesta activitat, i també els perjudicis que els pogués originar abandonar la seva llar per períodes llargs de temps, eren recompensats amb generositat (Ferragud 2005: I96-2IO). Amb tot, aquestes retribucions no foren consignades en les Ordinacions, i van ser organitzades en funció del que era habitual en l'estructura comptable en mans del mestre racional, com es veurà.

Doncs bé, abans del maig de I36o, Bartomeu de Tresbens va ser nomenat físic reial -rebent

4. En el temps que Tresbens estigué vinculat a la cort, Pere III nomenà almenys dotze metges més com a domèstics reials, residents en vuit llocs diferents (Ferragud 2005: 197). 
la familiaritas i esdevenint un domèstic més- de la cort de Pere el Cerimoniós, però segurament exercint alhora la funció d'astròleg, per bé que a les Ordinacions de la cort no es contemplava aquesta figura. El 30 de març de I36r, Bartomeu de Tresbens rebé el primer pagament de la casa reial (doc. 4). En seguiren dos més en el mateix any (docs. 5 i 6), un el I363 (doc. 7) i vuit pagaments més entre I372 i I373 (docs. II, I4, I5, I6, I7, I8, 24, 30). Els quatre primers pagaments es van efectuar en municipis aragonesos: el I36r a Saragossa i l’Almúnia, i el I363 a Montsó. S’evidencia una clara relació entre els desplaçaments del rei recollits en la seva Crònica personal en ocasió de la campanya aragonesa durant la guerra contra Pere el Cruel de Castella i les estades de Tresbens en aquestes poblacions aragoneses. Així, des d'Alagón, a uns $28 \mathrm{~km}$ de la capital del regne, el rei ordenà als ferrers de Saragossa que es posin a la disposició de l'astròleg el I5 de maig de I36o (doc. 3), durant el període en què la Crònica (Soldevila 20I4: 4, 29, 358) situa el monarca a la capital aragonesa i als seus voltants, entre finals de març i juliol, per protegir Aragó de les incursions castellanes. L'any següent el tresorer del rei fa dos pagaments a Tresbens, el 30 de març i a l'abril a Saragossa (docs. 4 i 5): Pere hi ha arribat el 22 de març i hi resta fins a mitjan abril del I36I (Soldevila 20I4: 4, 29, 359). Tot seguit es dirigeix a Calatayud per aturar l'avanç de Pere el Cruel (Soldevila 20I4: 4, 33, 364): consta un altre pagament del tresorer reial a Tresbens a l’Almúnia (doc. 6), localitat que cal identificar amb La Almunia de Doña Godina, situada entre Saragossa i Calatayud, de la qual dista uns $40 \mathrm{~km}$. Finalment, al cap de dos anys (abril de r363) retrobem el metge-astròleg a Aragó, aquesta vegada a Montsó (doc. 7), on el Cerimoniós havia convocat corts generals, que s’allargarien des del I5 de novembre de I362 al ı2 d'abril de I363, per obtenir recursos que cobrissin les despeses de la guerra (Soldevila 20I4: 4, 33, 364).

Quant a la funció principal que hauria tingut Tresbens durant la guerra, cal fer notar que era comú que un físic reial acompanyés el rei durant una campanya militar (Cifuentes I993: I, 219-60; 2, 34036I, 465-8 i 596-60I; Cifuentes 1998: 2O-27), però no hi ha evidència que es requerís la presència d'un astròleg en expedicions bèl-liques a la Corona d'Aragó. ${ }^{5}$ Això no vol dir que pogués oferir, a més dels de metge, els serveis astrològics, segons suggereix el document 3. La pau de Morvedre, signada el juliol de I363, va suposar una breu suspensió de les hostilitats (Belenguer 20I5: I79-I8I) i podria explicar l'aparent desconnexió de Tresbens respecte de la Corona. En efecte, resulta sorprenent que hi hagués un parèntesi de gairebé deu anys abans que tornem a tenir notícies documentals del vincle amb la casa reial. Segurament foren els anys que Tresbens romangué a Barcelona preparant els tractats d'astrologia que va escriure, temps en el qual sembla que el rei no li va demanar cap atenció en particular. També foren els moments en els quals es trobà implicat en dos plets a Aragó, l'un amb Marta de Buesa per una herència a Pina de Ebro (doc. 9) l'any r369, i l'altre amb Martín Pero Peregrín, ciutadà de Saragossa, per un motiu desconegut, l’any I370 (doc. Io). En tots dos el duc Joan hi intervingué a través de Miguel de Capiella, jurista de la capital aragonesa. No sabem si aquests plets són conseqüència de l'època en què formava part del seguici del rei o d'una nova estada al regne.

Quin tipus de servei estigué donant Tresbens a la monarquia entre I36o i I363, i posteriorment entre 1373 i I 375 ? Els conceptes pels quals percep remuneració corresponen a la seva activitat com a metge i astròleg reial, tot i que els documents comptables conservats no en donen detall. Amb ell se

5. No es pot descartar que en tant que astròleg Tresbens pogués donar algun consell per a la campanya militar amb alguna predicció, com ocorregué en altres contextos. Així, a Girolamo Manfredi se li encomanaren tasques delicades, com per exemple que escollís el moment més favorable perquè les naus de la croada contra els turcs promoguda pel papa Pius II el I464 es fessin a la mar, des d’Ancona (Carré 2004: IO-II). Dos exemples narrats per cronistes de derrotes militars com a resultat de prediccions astrològiques fatals són l’atac a Orzinuovi per Ezzelino da Romano, que va acabar amb la seva mort el ı259, i la desfeta de Pere I de Castella després de les previsions favorables d'Abraham ibn Zarzal i

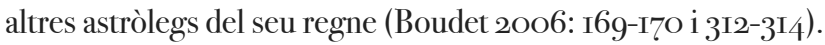


seguí el procediment habitual, pel qual el tresorer confirmava haver lliurat a l'individu interessat una quantitat, després que el metge hagués presentat l'albarà corresponent de l'escrivà de ració, seguint les ordres del mestre racional. En el nostre cas són sempre els registres del tresorer els que ens han deixat mostra d'aquest vincle. El més habitual a què es va referir el funcionari fou l'acorriment per la quitació, és a dir, un pagament ordinari que, com tota la resta de personal i també el sanitari, es rebia pels serveis prestats a la cort. El pagament es podia rebre en moneda diversa, també en florins d'or, i era calculat amb la moneda de compte habitual, bé la jaquesa d'Aragó o la barcelonesa de Catalunya. En ocasions s'especificaven els dies que hi havia estat present i pels quals rebia diners. Serà durant I373 que s'especificarà clarament els períodes, trimestrals, pels quals percebia 540 sous (docs. I5 i I7). El pagament venia a suposar uns 5 sous diaris; bastant important si pensem que un bracer d'aquell temps en podia cobrar 2, més encara si pensem que els dies de feina d'un metge reial eren realment pocs al llarg de l'any. El metge cobrava pel fet de romandre amb la cort.

Els pagaments també anaven relacionats amb les necessitats materials del domèstic reial. Així, en alguns pagaments es consignava que la quitació estava relacionada amb les bèsties que utilitzava en els seus desplaçaments, sempre distribuïdes segons el rang, que en el cas de Tresbens eren quatre (doc. 25). I quan aquests animals eren afollats, és a dir, incapacitats per alguna raó, la casa reial es preocupava d'indemnitzar l'afectat. Així li ocorregué a Tresbens amb un rossí, pel qual rebé 5 oo sous (doc. 35). A banda dels animals, la cort també subvencionava la despesa en roba. En I373 Tresbens rebé un d'aquests pagaments, consignat juntament amb el dels altres membres de la cort, de 360 sous en concepte del vestit (doc. I6). Aquest era un complement que la casa reial donava als seus membres, per tal que anessin abillats com corresponia a la seva categoria. Només tenim notícia que el rebés aquell any.

Finalment, en un parell d'ocasions rebé una donació graciosa, un pagament extraordinari que es feia al marge del convingut per la casa reial, per haver donat un servei del qual s'estava especialment satisfet (docs. I4 i 24). Mentre que la donació consignada al doc. I4, ordenada pel rei, no la podem atribuir amb certesa a cap prestació concreta, la concedida pel duc (doc. 24) deu estar relacionada amb la petició que li fa el setembre de I3722 d'anar-lo a trobar a València, aparentment per motius mèdics i astrològics (doc. 2I).

\subsection{Astròleg del rei}

Pere el Cerimoniós patrocinà les arts i les disciplines intel-lectuals amb l’objectiu de donar més prestigi a la monarquia. Entre els sabers fomentats pel rei destacà la ciència de les estrelles, que comprenia tant l'estudi dels moviments dels astres -l'astronomia- com la seva aplicació pràctica -l'astrologia-, i que va atènyer el seu moment d'esplendor en la Corona d'Aragó durant el seu regnat. Malgrat que l'interès de Pere per la ciència de les estrelles venia d'abans, és a partir de I359 que pren la forma d'un programa coherent i ambiciós de patrocini d'una sèrie d'obres d'orientació astronòmica $o$ astrològica a càrrec de diversos astrònoms-astròlegs associats a la Corona. Alguns d'aquests -Pere Engilbert (Cifuentes 2OI2-20I8: nomi89), Dalmau Sesplanes (Cifuentes 2OI220I8: nomi87) o el mateix Tresbens- hi mantenen un vincle més continu, mentre que altres, com Jacob Corsuno (Cifuentes 20I2-20I8: nomi86) o Jacob ben David Bonjorn (Cifuentes 2OI2-20I8: nom48), hi col-laboren de manera més puntual. Els tractats de Tresbens cobreixen el vessant astrològic del programa del rei, mentre que les obres dels altres autors tenen una orientació totalment astronòmica. Tresbens també es diferencia perquè la seva obra està escrita només en català, mentre que els altres empren, a més, el llatí i l'hebreu. L'infant i després rei Joan també s’interessa per la ciència dels astres, però no està provat que fomentés la redacció d'obres sobre aquesta disciplina. De fet, s'hi involucra d'una manera més personal que el seu pare, atès que 
demostra conèixer-ne la tècnica i consulta sovint els astròlegs. Justament la inclinació de Joan cap a les arts endevinatòries de diversa mena és un dels motius pels quals apareix condemnat al Purgatori en Lo somni de Bernat Metge i la raó per què hi va acompanyat per Tirèsias, l'endeví més cèlebre de la mitologia clàssica. ${ }^{6}$

Segons demostra la documentació de l'ACA, tots dos van incorporar llibres sobre astronomia i astrologia a la biblioteca reial i també van adquirir instruments astronòmics (Millàs Vallicrosa I962: 54-84; Chabàs I992: 39-251; Chabàs 2004: I5-37; Cifuentes 2O06: I89-22O; Ryan 2OII: IO5-I53; Macías 20I6; Véronèse 20I7; Giralt 20I8).

La dedicació de Tresbens a l'astrologia és prèvia a la seva arribada a Barcelona, si tenim en compte que, segons explica en el Libel d'investigació de tresors, ja va practicar-la al servei de Gaston de Lévis, senyor de Leran. És probable que aquest saber li facilités l'accés a la cort del rei Pere en qualitat de metge. En efecte, si va entrar al servei de la família reial cap al ı36o, com suggereix la cronologia dels documents coneguts, ho va fer just en el moment en què comencem a tenir constància continuada de l'interès del Cerimoniós per l'astronomia-astrologia. En aquest sentit pot ser significatiu que el més antic dels documents que vinculen Tresbens amb la Corona ja sembla tenir relació amb la ciència de les estrelles. Es tracta d'un requeriment del rei, datat el i5 de maig del I360 a Alagón, a prop de Saragossa, al justícia d’Aragó, Johan López de Sessé, perquè obligui a estar a la total disposició de Tresbens els ferrers de Saragossa que ell necessiti per a una obra que han de realitzar en les hores i dies que ell demani (doc. 3). No sabem de quina mena d'obra es tracta, però és molt temptador sospitar que devia ser algun instrument astronòmic.

No tornem a trobar un altre document susceptible de ser relacionat amb el servei astrològic de Tresbens a la Corona fins anys més tard. El I373 es troba a Barcelona quan, l’u de setembre, el duc de Girona escriu des de València al rei per suplicar-li que li enviï Tresbens amb urgència per un motiu indeterminat (doc. I9). El gran interès que hi té Joan resulta evident per les cartes que alhora escriu al mateix Tresbens i al seu propi armer, Joan Gener. Per desgràcia la carta al metge, més detallada, s'ha perdut, igual que l'adreçada a la duquessa pel mateix motiu. En canvi, sí que es conserva el missatge a l'armer, a qui encomana que faci tot el possible perquè Tresbens vagi a València, si cal proporcionant-li diners i cavalcadures (doc. 20). Encara més, el dia 4 insisteix amb una segona carta a Tresbens, en la qual li recorda la primera lletra i li demana que el vagi a trobar a València amb "tots los libres vostres e a vós necessaris axí en astrologia com en física ... per necessitat de nostra persona" (doc. 2I), i per carregar aquests llibres ordena que se li llogui una atzembla (doc. 22). Es desprèn, doncs, que les raons per a aquesta petició cal buscar-les en el seu paper tant de metge com d'astròleg, i que Joan les considera d’importància paral·lela. Per això sembla més probable que apel-lés a aquesta doble funció que no pas a l'aplicació mèdica de l'astrologia. El document 22, datat el 2I d'octubre, en el qual es reconeixen els diners avançats per la duquessa Mata d'Armanyac per al viatge, confirma que Tresbens va acudir a València des de Barcelona.

Al cap d'un any, l'octubre del I374, Tresbens torna a ser al regne de València al costat de Joan, segons indiquen dues cartes del duc. En una de datada el 23 d'octubre, com veurem més endavant, Joan li dona llicència per exportar figues del regne (doc. 26). Però aquí ens interessa sobretot la del 3I d'octubre del I374, en la qual, des de Sant Mateu, Joan escriu al seu pare, el rei, per pregar-li que rebi Tresbens i n'escolti el que deuen ser unes prediccions astrològiques sobre el monarca, l’hereu i els regnes de la Corona d’Aragó. Així mateix, li demana que, després d’haver-lo escoltat, li

6. “Jo m’adelitava molt més que no devia en ... cercar a vegades, així com fan comunament los grans senyors, en quina manera poguera saber algunes coses esdevenidores, per tal que pogués preveure e ocórrer-hi” (llibre II unitat 5; Badia ed. I999: 95). 
respongui a través del mateix Tresbens (doc. 28). És possible que hi hagi una relació entre aquesta petició i una altra del rei: en una lletra datada el 2 de desembre del I374, el rei fa anar Tresbens a Cervera, on es troba el monarca, per certs "afers nostres" que ha de portar a terme en col-laboració amb Dalmau Sesplanes, astrònom-astròleg també al servei reial, un dels autors de les famoses Taules de Barcelona (doc. 29). Per tant, sembla clar que aquests afers indeterminats també són de caire astrològic.

Trobem, doncs, les funcions d'astròleg reial reflectides amb parquedat i de manera poc definida en els registres de la Cancelleria reial, probablement per la natura confidencial dels afers que maneja, com suggereix la manera elusiva amb la qual s'hi fa referència (docs. 2I, 28 i 29). Aquesta és una de les raons per les quals esdevé difícil esbrinar quina és la influència real que podria tenir un astròleg en les decisions de govern. Sabem, per exemple, que Pere indica al mestre d'obres Guillem Carbonell, en una carta datada el I359, els dies i les hores més convenients per a col-locar la primera pedra de les obres que està a punt d'emprendre al Palau Reial Major de Barcelona, d'acord amb els càlculs de Pere Engilbert i Dalmau Sesplanes (Madurell I936). El I379 el duc Joan fa preguntar a Sesplanes quina és la millor data perquè Violant de Bar entri a Catalunya i perquè pugui celebrar les noces amb ella. ${ }^{7}$ Ara bé, en assumptes més complexos que les dates propícies per a l’inici d'obres o la realització d'unes noces, les indicacions dels astròlegs devien ser només un dels múltiples factors considerats per alguns prínceps especialment propensos a creure en la influència dels astres, com Joan, al costat de les nombroses recomanacions que devia escoltar de consellers o experts polítics, militars o religiosos (Giralt 20I8a).

Més enllà d'aquestes dades esparses, el paper d'astròleg reial s'evidencia sobretot en les importants obres astrològiques que va escriure Tresbens. Al'hora de redactar-les va optar pel català, la llengua del sobirà i del seu successor, que, malgrat no ser el seu occità matern, hi és propera, i no pas per la llengua comuna i habitual del saber universitari, el llatí. Es conserven quatre tractats astrològics de Tresbens, tots encapçalats per una dedicatòria a Pere el Cerimoniós, en dos manuscrits de la segona meitat del segle XV: el MS París, BnF, Espagnol 4II, que inclou tan sols el Llibre de les nativitats complet, l'obra més extensa, que ha estat editada amb el títol inexacte de Tractat d'astrologia (Vernet-Romano I957-1958) (Avenoza 1989-20I8: manid I87I; Cifuentes 2OI220I8: ms452; Giralt 2OI8), i el MS Ripoll, Biblioteca Lambert Mata, XXI, que transmet totes les obres conservades: a més del mateix Llibre de les nativitats (ff. Ira-85vb), conté tres escrits breus: el Tractat de les interrogacions (ff. 86ra-98rb, incomplet), el Tractat de les eleccions (ff. I5Or-I62v) i el Libel d'investigació de tresors (ff. I66r-I73v, incomplet) (Avenoza I989-20I8: manid 2II4; Cifuentes 2OI2-20I8: ms459; Giralt 2OI8b). Les obres de Tresbens constitueixen un corpus que aspira a oferir una visió de conjunt de l'astrologia. En efecte, amb el Llibre de les nativitats, el Tractat de les interrogacions i el Tractat de les eleccions Tresbens proporciona les bases en els tres àmbits fonamentals de l'astrologia judiciària sobre la fortuna humana: les nativitats, les interrogacions i les eleccions. Ara bé, la seva aportació s'orienta a les necessitats dels poderosos, especialment en els dos últims tractats. De fet, els prefacis dels tractats de Tresbens coincideixen a emfasitzar el valor especial que té l'astrologia per als reis i els nobles, ja que Déu els ha encomanat regir la resta de la gent $\mathrm{i}$, per tant, tenen gran necessitat de saber què ha de passar, quines accions han d'emprendre i quines passions i esdeveniments han d'evitar (Giralt 20I8a). Així ho manifestava Francesc Eiximenis quan exposava allò que els futurs reis havien d'aprendre d'infants:

7. "Volem que vós parleu amb en Dalmau Planes, stalabre, quals dies e quant dels meses de ffabrer, març e abril serien bons a entrar la duquessa en lo Principat de Cathalunya e axí matex a fer bodes” (9-I2-I379). ACA, C, reg. I746, f. 5or (citat en nota a Rubió I9o8-I92I: I, 28I). 
E aprés los és fort bo saber de astrologia, e açò per lur regiment de sanitat e per millor direcció de lurs faenes; car jatsia que tot bé devall de Déu, emperò moltes coses ha Déus comanades al regiment de les causes jusanes, ço és, del cel e de les esteles e de les planetes. Per la qual cosa, antigament, los reys passats en tots los grans fets e perillosos feyen, aprés la invocació divinal, guardar bona conjunció e constilllació sobre lurs faenes, e trobaven-s’i bé; e encara profitaria açò matex aytant com jamés se féu, sinó que seria gran perill per la gran malícia humana que los hòmens no lexassen tota confiança de Déu e no seguissen les esteles, ydolatrant a eles per fer-ne lurs afers (Witlin et al. ed. I986: I98-I99).

Encara degué encaixar més en els interessos específics del Cerimoniós l'objectiu més especialitzat de què s'ocupa el quart tractat de Tresbens, el Libel d'investigació de tresors, atès que la recerca de tresors i metalls preciosos va ser promoguda tant Pere com els seus successors, Joan I i Martí, concedint llicències amb aquesta finalitat a diverses persones, sens dubte empesos per les necessitats econòmiques de la Corona. Es pot sospitar que Tresbens es postula, amb el seu tractat, perquè el monarca el nomeni "cercador secret", encarregat de buscar coses amagades pels seus regnes, aparentment sense èxit (Giralt 20I8b). També sembla que tocaven temes específics altres obres que menciona com a escrites prèviament i que no han arribat a nosaltres, $\mathrm{o}$ com a projectes futurs que no van arribar a realitzar-se. Podem considerar perduts el Libre del Rey e de lurs accidents esmentat en les glosses del Libel d'investigació de tresors i una obra sobre un mirall per veure els enemics a distància. ${ }^{8}$

Aquí no podem allargar-nos sobre els tractats de Tresbens, però sí que val la pena que fem una valoració de la seva significació: en el marc de la bibliografia astrològica original, amb escassa presència de les llengües vernacles enfront del llatí -si no comptem les traduccions-, la seva obra mostra una ambició molt superior a la de qualsevol autor astrològic anterior o contemporani en llengua vulgar. Es tracta, a més, d'un autor astròleg, que exerceix com a tal, i no pas d'un autor aliè a l'astrologia. En les seves obres, Tresbens cita i demostra conèixer un bon nombre de les principals autoritats de l'astrologia medieval, majoritàriament àrabs. Malgrat que la seva font més habitual és Ibn Abī-l-Riǧāl (Abenragel; Cifuentes 2OI2-20I8: nomı2I5), també recorre a Omar Tiberíades (Umar ibn al-Farrukhān al-Ṭabarī), Abū Ma šar (Albumasar), al-Qabīṣī (Alcabici; Cifuentes 2OI220I8: nomı2I9), el pseudo-ptolemaic Centiloquium, el recull Liber novem iudicum, Ptolemeu i Māšāàallāh ibn Atarāī (Messahala; Cifuentes 2OI2-2OI8: nom784).

Tresbens, però, no és un simple compilador, atès que de vegades cita les autoritats de manera crítica, contraposant-les entre elles o a la seva pròpia experiència o opinió. Complementa l'explicació teòrica amb exemples i raonaments propis, aplicant la tècnica a casos concrets. En Tresbens trobem, doncs, un autor format a la universitat que difon un saber altament tecnificat com és l'astrologia, que empra metodologies escolàstiques -confrontació d'autoritats, comentari, qüestions-i les combina amb la seva experiència pràctica però servint-se de la llengua vernacla per al públic al qual va destinat: la reialesa. Un autor, dones, que crea saber en vulgar, i que és un dels exemples més destacats del procés de diversificació de la creació i la difusió del saber que es dona a l'Europa baixmedieval.

Si abordem la cronologia de les obres de Tresbens, hem d'admetre que no les podem datar amb certesa. De fet, l'únic que podem assegurar és que el Llibre de les nativitats va ser escrit quan l'autor tenia més de 47 anys, per una referència que fa al naixement del seu fill (Vernet-Romano I957-I958:

8. L'índex del MS Ripoll, Biblioteca Lambert Mata, XXI, es clou amb la referència a un text "En fer mirall de què hom veja sos enemichs de meieja jornade" (f. 2v), que devia ser el Mirall de Plató esmentat al f. i62v del mateix còdex. En tot cas, no s'hi conserva per la pèrdua dels darrers folis del volum. Agraïm a Lluís Cifuentes que ens hagi fet aquesta observació. 
I, I3O-I3I), però atès que ignorem la data del seu naixement aquesta dada no permet datar el llibre. Això sí, les referències internes fan pensar que les obres van ser escrites en el mateix ordre en què estan disposades en el manuscrit: Llibre de les nativitats, Tractat de les interrogacions, Tractat de les eleccions i Libel d'investigació de tresors.

Tanmateix, un seguit d'indicis deixen entreveure que la redacció de les quatre obres es va fer en el decurs de la dècada de I36o, i més probablement a partir de 1363 , coincidint amb el parèntesi documental en la seva relació amb la Corona. En primer lloc, en dues de les obres trobem dues referències a fets contemporanis, tot i que massa vagues per tenir-ne cap certesa. En el Tractat de les interrogacions hi ha una possible al·lusió a la intervenció d'Anglaterra en la guerra entre Pere el Cruel i Enric de Trastàmara (I366-I367) quan planteja una interrogació sobre "lo rey d'Anglaterra si conseguirà lo regne de Castella". ${ }^{9}$ D'altra banda, en el Tractat de les eleccions recorda un "consell" del rei amb els nobles de Catalunya que va pronosticar encertadament -a l'arquebisbe de Saragossaque no tindria efectes. ${ }^{\text {Io }}$ Aquest "consell", que s'hauria celebrat en un passat recent i, per tant, no seria contemporani de la redacció de l'obra, podria correspondre al parlament que va reunir els nobles i els eclesiàstics catalans convocat pel rei el ro de juliol del I362, segons recull el cronista Jerónimo Zurita."

Atès que, segons indica la distribució en el manuscrit de Ripoll, el Libel d'investigació de tresors degué ser l'última escrita de les obres conservades de Tresbens, dos documents reials que semblen referir-se a aquest opuscle podrien servir per indicar el terminus ante quem del conjunt de l'obra preservada de Tresbens. El primer és una carta enviada pel rei des de València a Pere Ramon, a Barcelona, en la qual li ordena amb vehemència que li enviï una còpia ben revisada del "libre sobre tresors amagats" que se li havia manat realitzar per al mateix monarca (I3 setembre I369). ${ }^{.2}$ En l'altre, d'uns dos mesos abans, la tresoreria del rei feia un pagament per cobrir les despeses d'un "llibre d'astrologia" per al rei, que potser hauria estat destinat a costejar aquesta còpia. ${ }^{13}$ A partir d'aquestes dades, doncs, sembla raonable defensar que el Libel d'investigació de tresors va ser acabat a mitjan r369 o poc abans. En conseqüència, tots aquests indicis permeten plantejar com a hipòtesi que l'obra conservada de Tresbens va ser escrita entre I363 i I369.

9. f. 89r. Cf. Soldevila 20I4: 4, 59-6I, 393-395.

Io. "E remembre mi que lo rey féu un consell ab tots los barons en Catalunya e yo viu que termeneren lo consell e yo diguí a l'archabisbe de Saragossa que notàs bé aquella cosa que yo li diria: que ja res no se’n seguiria d'aquella determinació per ço car la luna era adonchs en la 6 casa e axí fo, per què guardats tots temps que la luna non sia cazent”, f. 158 r.

II. "Y el rey a Io de junio mandó convocar todos los prelados y barones de Cataluña para que se juntasen en Barcelona a Io de julio siguiente” (Zurita I967-I985: 9, 40; 4, 436).

I2. "Lo rey. Manam-vos sots pena de la ira e indignació nostra que per lo feel nostre Bernat Grimau, mercader de Mallorca, portador de la present, nos trametats trellat bo e feelment fet e comprovat del Libre dels tresors amagats, lo qual vos fou liurat per manament nostre, havent-vos en açò leyalment segons que de vós confiam”. ACA, C, reg. I225, f. 44r (Rubió I9o8-I92I: 2, I59, núm. i62, en corregim la signatura).

I3. "Ítem, done al senyor rey, los quals lo dit senyor, ab albaranet segellat ab lo segell del seu anellet, scrit en València a XXI dia de juliol de l'any M CCC LXIX, atorgà de mi haver haüts e reebuts per messions que·s són fetes en un llibre d'estrologie del dit senyor, segons que en lo dit albarà se conté, que cobre: XXII florins d'or d'Aragó". ACA, RP, MR, vol. 358, f. 66v, editat a Trenchs (20II: 376, núm. I423). Encara que la proximitat cronològica amb la carta anterior és significativa, aquest document també podria estar relacionat amb un pagament a Dalmau Sesplanes, com en ACA, C, reg. I344, ff. 22v-23r (6-I-I367), editat a Trenchs (20II: 360-36I, núm. I354). 


\section{$3 \cdot 3$ Físic de la casa reial}

Tresbens era per damunt de tot un físic, amb una sòlida formació universitària aconseguida a Montpeller. Així s'intitulà personalment i així el consideren els funcionaris de la Cancelleria (“metge de física de casa del senyor rey”). Tanmateix, ben poques són les notícies sobre els aspectes relacionats amb la pràctica mèdica desenvolupada per ell en la cort. De fet, no hi ha pràcticament res sobre la seva actuació clínica. El contingut dels documents no és prou explícit en moltes ocasions, i la majoria de les vegades no podem saber, quan era requerit pel rei o els infants, quins n'eren els motius. Amb tot, és de ben suposar que l'atenció mèdica n’havia de ser un d'aquests motius.

Només en una ocasió aquesta documentació administrativa i cortesana explicita una malaltia a tractar. Fou quan el Io de desembre de I374 la infanta Mata d'Armanyac el va requerir a Lleida perquè li tractés un refredat amb febre (docs. 3I, 32, 33 i 34; Javierre I930: 76). Un document anterior, datat el 2I d'octubre de I373, fa pensar que Tresbens acabava de començar la relació amb ella. Això és completament versemblant, ja que sabem que Tresbens havia ingressat com a domèstic de la casa reial l'i de setembre anterior (doc. 25). En aquell octubre, l'infant Joan informava que el dispenser de casa de la seva esposa havia avançat algunes quantitats a diversos dels domèstics, i entre ells Bartomeu (doc. 23). Bé podem pensar que es tractava de la necessitat mèdica per la qual el duc el feu anar a València amb els seus llibres de física i astrologia, com hem vist (doc. 2I). Això indicaria que l'astròleg fou el primer metge en qui va confiar la duquessa, atès que el matrimoni amb el futur Joan I havia tingut lloc el 24 d'abril de I373, a penes mig any abans. Doncs bé, el cas és que la malalta reclamà Tresbens a la seva presència dues vegades aquell hivern de I374 i escriví al rei perquè l'autoritzés a sortir sense dilació. Tanmateix, passats els dies, Tresbens no hi havia acudit. Segurament per això, el 2I de desembre el metge i professor de l'Estudi General de Lleida, Nadal Llambrí, va rebre Io florins en pagament visitando nos in infirmitate quam in dicta civitatis habuimus. ${ }^{\mathrm{I}}$ Encara al gener foren cridats Bernat de Berriac i Guillem Colteller (Cifuentes 20I220I8: nom3I3I), amb urgència, per tractar la seva malaltia, que havia empitjorat (doc. 34). Tots dos reberen missiva del primogènit reial, com també el batlle de Girona i el seu dispenser, per tal que insistissin respectivament a Colteller i Berriac en la seva partida, i els la facilitessin. ${ }^{15}$ Potser fou aquesta manca de diligència de Tresbens el que va fer que mai més fossin sol-licitats els seus serveis mèdics. A partir d'aquell moment, la duquessa de Girona tingué dos metges que l'atengueren a ella personalment i els seus fills en reiterades ocasions: Guillem Colteller i Juan de Ordás, el primer català i el segon aragonès, per bé que no serien els únics a ser sol-licitats (Javierre I930: 75-77). Guillem Colteller era un físic amb enorme prestigi, vinculat a la casa del rei Pere i a la del seu fill Joan (Roca I922; Ferragud 2005). Ordás també estigué molt de temps al servei del monarca i la seva família, i fou aquest el que atengué la reina en la seva darrera malaltia (Javierre r930: 77). Pel que fa a Berriac, que també l'havia visitat, igualment va prestar atencions mèdiques a la família reial, a més de ser comissionat per examinar els metges no titulats de la Corona, com veurem.

Ben al contrari del que va succeir amb l'astrologia, una faceta que va desenvolupar notablement al servei de la monarquia, com hem vist, no sembla que la medicina fos l'habilitat que més va interessar Tresbens. Costa concebre que la casa reial mantingués la confiança en un metge que va estar durant tants anys distanciat de la cort, o almenys així ens ho mostra la documentació. El que sí que podem afirmar és que el seu prestigi com a físic transcendí la casa reial. Així s’ha d'entendre que fos temptat pel Consell de Cervera, en l'any I372, per a pensionar-lo com a metge, circumstància que

I4. ACA, C, reg. I809, f. IO7̧v (2I-I2-I374). Sobre Llambrí vegeu Camps (1998).

I5. ACA, reg. I740, ff. 49r-v (22 i 23-I-I374). Javierre (1930) va donar erròniament la signatura, ja que va indicar el número 1749 en lloc de I740. 
analitzarem més endavant.

Aquesta influència mèdica interna i externa a la cort, més enllà de la mera atenció mèdica a la família reial i els seus domèstics, s’evidencia en el paper que va desenvolupar en el control dels practicants de la medicina que exercien en determinats territoris de la Corona.

\section{Regulació dels practicants de la medicina}

$\mathrm{R}$ Resulta sorprenent que el primer document del qual tenim notícia, i que indica que Tresbens s'havia establert a la Corona d'Aragó, sigui l'examen a Jaume de Pallars el març del I359 (doc. I). Els metges que solien formar part de tribunals eren els instal-lats, ben coneguts, amb fama de bons professionals, prestigiosos, com els que apareixen en aquest tribunal al costat de Tresbens: Pere Ros, metge reial des d'almenys I343, Arnau Germà, un prestigiós metge de Barcelona i futur metge municipal, i Ramon de Teserac, el metge municipal del moment. ${ }^{16}$ Sobta que un nouvingut ocupés un lloc d'aquesta rellevància, i al costat d'individus per contra molt ben coneguts i consolidats dins la ciutat de Barcelona. O ja estava arrelat a Barcelona i s'havia guanyat un prestigi, o bé va exhibir una carta de presentació que va convèncer immediatament tothom de la seva vàlua. En tot cas, la seva alta consideració li permetria ben aviat, abans del maig del I36o, entrar al servei de la Corona.

Segons el document, l'examen de Jaume de Pallars - a qui es dona el títol universitari de mestre, però no s'especifica si és mestre en medicina o en arts- es fa d'acord amb els capítols, de les corts de Montsó, aplicables només a Catalunya, convocades per Alfons el Liberal el ı289, que establien que, per poder exercir, un metge -igual que els notaris i cirurgians- abans havia de passar un examen realitzat per prohoms locals i per altres metges, i fer el jurament de comportar-se lleialment en l'exercici de la seva professió. ${ }^{17}$ L'examen té lloc el 22 de març del I359 a Barcelona, en una casa del notari Simó de Rovira, escrivà del Consell de Cent, en presència de cinc consellers de la ciutat, tres mercaders i tres cirurgians com a testimonis, a més de quatre mestres en medicina, entre els quals Tresbens. Aquests metges han estat assignats pel lloctinent del veguer de Barcelona i del Vallès i, després d'un jurament, han examinat el candidat fent-li nombroses preguntes i plantejantli arguments per comprovar la seva aptitud professional. En acabat, els metges examinadors declaren apte el candidat tant pel que fa al coneixement de la medicina com pel que fa a la seva pràctica. Immediatament, Jaume de Pallars fa el jurament que es comportarà lleialment i legalment en la dispensació de medicaments, en les visites, en els informes pericials i en els altres aspectes relacionats amb la professió. Tenim algunes dades de la trajectòria posterior de Pallars per altres fonts: es casà i es traslladà pocs anys després a Sardenya, on va exercir la medicina al servei de la Corona, cobrant un salari anual com era preceptiu. ${ }^{18}$ Tanmateix, en el mes de setembre de I362 ja era

I6. Germà i Teserac havien estat examinadors a l'octubre del mateix any d'un altre metge: AHCB, Estudi General, CC - XVIII - 9, 2. Les destacades trajectòries professionals de tots tres són conegudes, tal com es pot veure en Torre y del Cerro-Rubió (ı971: 40-42).

I7. "XVIII. Item ordinamus et statuimus quod aliquis jurisperitus non utatur in aliqua causa inquisitionibus advocatoribus neque de judicamento donec examinatus fuerit per probos homines uniuscuiusque loci simul cum aliis sapientibus jure; et quod illi qui fuerint ellecti jurent quod fideliter se habebunt in advocationibus et in aliis rebus in posse vicarii vel baiuli et dictorum proborum hominum dicti loci.XIX. Item ordinamus et statuimus quod illud idem fiat in medicis et cirurgicis. Item quod illud idem fiat in notariis publicis”. ACA, C, reg. 80, ff. I337-v (I4-3-I289). Publicat en González I975, 2, 387, doc. 255. El document, en la seva versió catalana, va ser editat en Torre y del Cerro-Rubió (i97ı: 3, doc. I), amb una errada en el número de constitució. Vegeu també aquest document amb comentaris respecte del tema en Cifuentes (1993: 576).

I8. El I36r ja estava cobrant 5o lliures d'alfonsins menuts. ACA, RP, MR, vol. 2o82, f. 99 (5-4-I362). 
mort i la seva esposa Margarida havia quedat pobra i desprotegida, i reclamava del veguer béns per Ioo lliures que havien restat a Castell de Càller que li pertanyien, així com els 3.ooo sous del seu dot. ${ }^{19} \mathrm{El}$ rei Pere escoltà el clam de la viuda i exigí aquests pagaments.

Les disposicions del rei Alfons deuen ser la primera actuació d'aquesta mena impulsades per la Corona d'Aragó. McVaugh (I993: 70-7I) en discuteix l'abast. Potser és un problema de visibilitat documental, com també que van arribar a aplicar-se només després de la seva confirmació en corts posteriors (vegeu també García Ballester-McVaugh-Rubio Vela I989: 3-4). Aquests capítols van ser sancionats per Pere el Cerimoniós en les Corts catalanes de Cervera de I358-59 (cap. XII), en les quals, a més, s'exigeix a qui practiqui medicina que hagi estudiat tres anys a la universitat. ${ }^{20}$ Així doncs, la preocupació reial per assegurar la competència dels professionals mèdics va creixent amb el pas del temps. En efecte, a les corts de Montsó, celebrades pel mateix Pere el I363 (cap. XVII), es concreta amb més detall com serà l'examen de jurisperit, que es posa com a model per al de metge, i es donen instruccions específiques sobre els exàmens dels practicants mèdics jueus i musulmans, al tribunal dels quals s'assignen metges de la seva mateixa religió al costat d'un metge cristià. Si no fos possible, el tribunal estaria compost per dos metges cristians. Aquesta legislació, promulgada per diverses corts, es recull a les corts de Barcelona de $1368-\mathrm{I} 369,{ }^{21}$ i s'integraria a les compilacions de les constitucions de Catalunya iniciades el I4I3. ${ }^{22}$

No podem fer aquí un estudi aprofundit d'aquesta qüestió, malgrat la seva importància, però sí que val la pena assenyalar que a l'ACA es conserva documentació abundant que demostra l'interès del rei Pere i del duc Joan pel control de les professions sanitàries en tots els seus regnes; en alguns casos, específicament al Principat, apel-lant a les constitucions de Catalunya com a fonament legal. Les més nombroses són les llicències atorgades tant pel sobirà com pel seu primogènit a metges $\mathrm{i}$ cirurgians de tots els territoris de la Corona, normalment després de ser examinats, però de vegades eximint-los-en. Freqüents són també els documents relatius a la realització d'exàmens: s’hi ordena a les autoritats locals fer els exàmens i buscar examinadors, $o$ als metges participar en els tribunals. Altres documents prohibeixen i sancionen alguns guaridors, com barbers o apotecaris, per exercir la cirurgia o la medicina sense llicència o sense haver fet els cursos preceptius a la facultat de medicina.

I9. ACA, C, reg. IO36, ff. IOv-II (6-9-I362).

20. "Quod nemo jurisperitus audeat assumere officium advocacionis iudicis vel assessoris nisi audiverit per V annos in studio generali et fidem fecerit et medicus per III annos. Confirmantes insuper capitulum in dicta Curia Montissoni editum quod incipit item ordinamus et statuimus, etc., ac eidem adhicientes statuimus quod aliquis jurisperitus in civitatibus, villis et aliis insignibus locis nequeat advocare nec officium iudicis vel assessoris assumere nisi omnes quinque libros ordinarios iuris canonici et quod omnes ipsos audiverit per quinque annos in studio generali de quo per sacramentum fidem facere teneatur et idem de medicis artis fisice volumus observari detracto quod sufficiat ipsum in generali studio per tres annos solummodo audivisse" (cap. XII). Cortes r896: 2, 48.

2г. Document conservat a l'AHCB i a l'ACA: el de l'AHCB (Llibre vermell, II, f. 22rv, i Llibre verd, II, f. 36v) està reproduït a Gómez (2006) i el de l’ACA (reg. 985, f. I67r) està reproduït per Rubió (I9o8-I92I: I, 2I9-22I, núm. 227). Tanmateix, reproduïm aquí la versió catalana de les Constitucions catalanes de I495, més completa pel que fa a les professions mèdiques: "Statuïm e ordenam que negú savi qui doctor o aprovat no sia offici de assessor, de jutge e de advocat d'aquí avant regir o prendre no gos o presumesca, si donchs primerament ell en poder de l'official ordinari no haurà fet públicament en la cort sagrament que per cinch anys en estudi general dret canònich hage hoït, o civil, e per dos savis de les cites ciutats o viles, si dos n’hi haurà, $o$ almenys hu, en presència del dit official examinat serà e aprovat. (...) E açò mateix sots les dites penes sia observat en los metges christians de art de físicha, en los quals, emperò, abast aquells per tres anys en general estudi haver estudiat e oït los libres ordinaris de la sciència de medicina. Los juheus, emperò, e sarraïns metges hagen ésser examinats per metges de lur ley o secta, si algú n’hi haurà, emperò hu metge christià ajustat en lo examen de aquells e, metges de aquella ley o secta no havents, hagen ésser examinats per dos metges christians. La qual examinació feta, si sufficients seran trobats, hagen a jurar públicament bé e leyalment praticar ans que a la pràctica sien admesos" (Font i988: 219).

22. Font I988: 2I8-2I9 (facsímil de l’edició de I495, ff. 7 IV-72r). 
Així mateix, hi ha requeriments a autoritats municipals de Catalunya perquè no permetin l'exercici de la cirurgia sense un examen previ, d'acord amb el que s'estableix a les constitucions catalanes.

També hi trobem certs encàrrecs més generals que podríem considerar precedents de la figura de protometge, un físic a qui el rei conferia el control de la professió. Així, el I373 el rei faculta el físic Bernat de Berriac per examinar tots els qui exerceixin la medicina en els seus dominis sense tenir el títol de mestre en medicina, amb la multa consegüent per als guaridors que no compleixin aquest requisit i la prohibició d'exercir per als qui no superin l'examen. ${ }^{23}$

Tresbens va estar a punt d'atènyer un control encara més extens sobre la professió mèdica de la Corona d'Aragó, a través del primogènit del Cerimoniós, Joan, quan aquest intentà impulsar una regulació sanitària, que degué ser-li inspirada pel mateix astròleg. Així ho reflecteix un document, datat l'iı d'abril del i375, en què l'infant, des de Saragossa, li encomana una comissió per al control de la pràctica mèdica no reglada (doc. 36$)$. En les consideracions, Joan es mostra sabedor d'un seguit de pràctiques fraudulentes per part de guaridors incompetents, que el preocupen pel perjudici que poden provocar a la salut dels seus súbdits fins al punt de posar-ne les vides en perill. Així, manifesta que molts homes i dones de diverses religions exerceixen, en el regne d'Aragó, l'art mèdica i quirúrgica de manera indigna i temerària a causa de la seva imperícia. També denuncia la mala praxi de nombrosos apotecaris, que administren medecines falsejades, inadequades o fetes malbé, sense recepta de metges competents, o bé que, en utilitzar els repertoris de quid pro quo que donaven equivalents locals per a simples recomanats per les autoritats mèdiques-, posen en el preparat un altre ingredient en comptes del que toca.

A fi de combatre aquests abusos, Joan dictà una sèrie de disposicions, tant en defensa de la justícia, com de la utilitat pública i de la protecció dels súbdits. Joan establia que el comissionat hauria de posar a prova tot home o dona de qualsevol religió que trobés en el regnes d’Aragó i de València, així com en la resta dels dominis de la Corona exercint l'art mèdica, física i quirúrgica, en les condicions que fossin, exceptuats els professors o llicenciats universitaris. Aquesta prova havia de consistir en un examen rigorós i suficient que s'havia de realitzar per mitjà d'un metge, acompanyat d'alguns oficials de la Corona o prohoms locals. Fins i tot es podia fer certificar per un notari públic. Així mateix, havia de fer inspeccionar els apotecaris i els materials que tenien en les seves parades per part d'un jurat del mateix ofici acompanyat d'un notable o un mostassaf (inspector dels mercats) local. Un cop fets l'examen i la revisió, calia fer cremar els medicaments inútils i atorgar una llicència reial als metges que consideressin aptes per exercir la pràctica. ${ }^{24}$ En canvi, aquells que el metge comissionat no trobés competents, els havia de fer tornar a estudiar, si hi tenien una bona disposició, mentre que havia d'apartar de la pràctica mèdica els xarlatans i els guaridors ambulants, prohibint-los dedicar-s'hi sota les penes que creguin adequades, incloent-hi el vessament de sang, però no la mutilació o la mort -penes que es reserva la Corona. Joan també disposava que, per mandat judicial o dels oficials reials, i quan les parts no es posessin d'acord, el metge comissionat pogués taxar els salaris dels metges, peritar els ferits i inspeccionar tots els altres aspectes relatius a les medecines i els malalts. A més, si calgués nomenar algun metge amb aquesta finalitat en alguna província, el dit metge hauria de ser un professor, o almenys un llicenciat en medicina competent. Amb la finalitat de dur a terme la seva funció, l’infant posava a disposició

23. ACA, C, reg. Io88, f. I5r, editat en López (1952: I69, doc. 65). No s’ha de confondre aquest Bernat de Berriac amb el seu pare homònim, mort el I348, que va tenir una carrera mèdica molt més destacada.

24. El I4O3, un fur promulgat per Martí l'Humà a València va sancionar definitivament aquest procediment. Cada any el justícia civil hauria d'escollir, d'acord amb els dos metges examinadors de la ciutat, dos apotecaris experts que controlessin la qualitat del que es feia als diferents obradors, sis vegades a l'any i amb l'acompanyament del mostassaf. Si trobessin que els materials no eren aptes ni de qualitat suficient, el mostassaf n'hauria d'ordenar la crema (Colón-Garcia I999: г38-I39). 
del comissionat tots els oficials municipals i reials, que havien d'obeir-lo, no obstaculitzar la seva missió, i impedir que ningú altre l'obstaculitzés, sota pena de multa.

Si s’hagués arribat a aplicar, aquesta hauria estat la intervenció més ambiciosa de la monarquia catalanoaragonesa en la salut pública fins a aquell moment, perquè hauria afectat tota mena de practicants mèdics no universitaris, inclosos els apotecaris, i perquè anava més enllà de l'establiment d'un sistema d'exàmens. Tanmateix, la documentació posterior demostra que la regulació impulsada pel duc només va quedar en paper mullat. En efecte, uns dies després, en una carta datada el 28 d'abril que Joan envia a Tresbens (doc. 37), aquell li demana que no tiri endavant cap acció relativa a les disposicions sobre la professió mèdica que li han estat encomanades si abans no les aprova el rei per escrit. Aquesta brusca aturada ens pot fer sospitar que el rei no va acceptar de bon grat la iniciativa del primogènit, segurament perquè s'esperava l'oposició de municipis, gremis i col-legis a la seva ingerència. Així ho fa pensar una ordre emesa pel Cerimoniós des de Lleida al cap de poc, el 20 de maig del I375, que estableix una regulació diferent, menys complexa, per al regne d'Aragó, amb el pretext que alguns metges titulats quan fan d'examinador concedeixen la llicència per exercir medicina o cirurgia empesos per afecte o per favor, exigint diners o rebent obsequis, amb el consegüent perjudici públic causat per la pràctica criminal d'aquests professionals il.legítims. ${ }^{25}$

Pere confia al metge reial Berenguer d'Alòs, resident a Saragossa, l'encàrrec d'examinar i decidir si són aptes per rebre una llicència mèdica tant aquells que han actuat d'examinadors en el passat com aquells que vulguin, en el futur, exercir la medicina a Saragossa i al regne d’Aragó. També el faculta perquè, si són considerats no aptes, els prohibeixi d'exercir la medicina o la cirurgia fins que siguin aprovats. Per si queden dubtes de l'objectiu d'aquesta norma, una clàusula final revoca qualsevol comissió feta prèviament per qualsevol altre sobre aquesta qüestió, abans de donar a Berenguer poders plens davant les autoritats aragoneses per tirar endavant l'encàrrec. ${ }^{26}$ Així doncs, sembla clar que l'objectiu d'aquesta nova regulació és barrar el pas a la impulsada per Joan, encara que sigui d'una manera més aviat improvisada, possiblement per considerar que el primogènit

25. Sabem que els metges actuaven de vegades arbitràriament moguts per interessos particulars, tendint a perjudicar o beneficiar determinats individus (Ferragud 2OII).

26. "Nos Petrus, et cetera, quia intelleximus pro constanti quod aliqui medici qui nominati sunt magistri vel in medicine scientia graduati examinatoris officium assumentes in civitate Cesarauguste et regno nostro Aragonie aliquociens amore, aliquociens favore, aliquociens causa extorquendi pecuniam seu habendi encennia, alios examinant dando eis phisice et cirurgie arte licenciam utendi, imo pocius abutendi et eciam exercendi. Quos si bene inspiciamus, reputantur illegitimi ad tale officium assumendum et tale examinati perversorum audaciam assumentes utuntur, imo, ut permittitur, abutuntur pratica medicine ob quod multa mala et scelera perpetrantur et subsequntur nostre rei publice dampnum irreparabile et evidens nocumentum. Idcirco volentes utilitati nostre rei publice providere confidentesque de fide, industria et legalitate vestri, fidelis phisici domus nostre Berengarii d'Alos, licenciati in medicina, volumus et ordinamus quod tam illos qui retroactis temporibus dictum examinacionis officium assumpsserunt, cum officium examinandi nulli competat nisi examinato, et sic perconsequens magistro vel licenciato in medicina, quam illos qui de cetero praticam medicine voluerint exercere in dictis civitate et regno, nunc per tunc et econtra bene et fideliter examinetis et si aptos et sufficientes eosdem reperitis volumus per nos de nostri mandato utendi arte medicine licentiam impartiri. Si vero ineptos et insufficientes reperitis, eos inhibeatis penis et aliis cohercionibus quibus vobis videbitur, ut in dicta fisica seu cirurgia utantur nullatenus seu exerceant ipsius practicam, donec sufficientes fuerint idonei atque apti et eciam aprobati, et quoscumque volentes uti ultra formam predictam ad dictos olim examinatores, si vobis consisterit circa predictam in aliquo deliquisse eosdem rigide puniatis prout de foro et ratione inveneritis faciendum. Nos enim revocata ex causa per nos quacumque comissione super predictis alicui alii facta, vobis super predictis vices nostras comittimus plenarie cum presenti iniungentes expresse iusticie Aragonum ceterisque officialibus et subditis nostris regnorumque officialibus locatenentibus presentibus et futuris in et super predictis vobis prestent auxilium, consilium et favorem, si et quando a vobis inde fuerint requisiti. In cuius rei testimonium dant nobis fieri et sigillo nostro pendenti iussimus comuniri. Data Ilerde $X X^{\text {a }}$ die madii anno a Nativitate Domini $\mathrm{M}^{\circ} \mathrm{CCC}^{\circ} \mathrm{LXX}^{\circ}$ quinto, regnique nostri quadragesimo...”. ACA, C, reg. 927, f. I48v (20-5-I375). 
s'excedia en les seves funcions.

Pel que fa al seu inspirador, si tenim en compte que els darrers documents coneguts sobre Tresbens -emesos per Joan- són del 28 d'abril del I375 (el tot just esmentat doc. 37 i el 38), no sembla aventurat pensar que degué caure en desgràcia davant el rei de resultes del xoc entre aquest i el seu fill, amb la conseqüència immediata que es vagi trencar el vincle de Tresbens amb la Corona. Això explicaria per què, de cop i volta, el perdem de vista en la documentació reial. Malauradament, no coneixem fonts ulteriors que ens permetin saber més enllà d'aquest punt de la seva vida: si va seguir la seva carrera o es va retirar, si restà a la Corona d’Aragó o tornà al seu país d'origen.

\section{Amb bon ull per als negocis}

Els metges de la Corona d'Aragó, particularment aquells amb més recursos econòmics i, cal suposar, aquells vinculats a la casa reial, esmerçaren els seus guanys en diverses activitats productives i mercantils (Ferragud, 2005: 249-468). En el cas de Tresbens aquests negocis no es documenten a Barcelona, sinó que sembla que es van anar desenvolupant al llarg del seu seguiment de la cort. Segurament emparat pel seu prestigi i la confiança que inspirava com a membre de la casa reial, i les garanties de solvència que podria donar en el transcurs dels negocis, aconseguí desenvolupar-los amb èxit. Així doncs, l'astròleg degué començar amb el coixí dels guanys assolits en la seva etapa occitana, al servei del senyor de Leran o d'altres personatges. Com resulta evident per alguns documents, Tresbens no va perdre mai el contacte amb els seus orígens. Hi conservà relacions amb alguns personatges (doc. I2), propietats i llibres, que hagué de mirar d'aconseguir en moments puntuals (doc. 27).

Una de les estratègies més comunes que podia seguir un inversor era el mercat del crèdit. La difusió cada vegada més gran dels censals i els violaris havia fet que qualsevol que tingués diners acumulats i disponibles hi veiés un bon recurs per rendibilitzar capitals (García 2002). Individus privats, grups menestrals i pagesos, però molt particularment també nobles i burgesos, municipis -sempre endeutats-, o institucions civils o eclesiàstiques, podien demandar capitals necessaris per fer front als assumptes més diversos. Només tenim un indici que indiqui que Tresbens hagués prestat diners.L'octubre de 1363 , el rei Pere va ordenar un sobreseïment de sis mesos abans de fer execució dels béns de dos veïns de Saragossa, Ferrando López de Sesé i Johan d’Arcayna, els quals havien manllevat una quantitat a Tresbens (doc. 8). Els López de Sesé eren una notable família de la noblesa mitjana-baixa aragonesa. Un membre de la nissaga, Johan, ocupava el càrrec de justícia d'Aragó des de I349 (Campo 2007: 25-26), i havia tingut ja contacte amb Bartomeu per l'assumpte dels instruments requerits als ferrers de Saragossa (doc. 3 ). Temps a venir, la família tindria cert protagonisme en l'entronització de Ferran d'Antequera en el soli de la Corona d'Aragó, en ser partidaris dels Luna (Sarasa 20I5: 2OI; Muñoz 2OI5: 877). Un homònim acompanyà el comte de Luna, Frederic d'Aragó, en l'expedició d'Alfons el Magnànim a Nàpols. De fet, fins i tot rebria una deixa en el testament del comte (Sáiz 2008: I47-I52). Comptat i debatut, podem afirmar que Tresbens ja havia establert relacions amb personatges de certa rellevància poc després d'arribar als territoris de la Corona.

En tot cas, sí que sabem que Tresbens estigué endeutat en diversos moments. El primer, el I360 (doc. 2). Es tracta dels diners rebuts en una comanda, mètode que s'utilitzà de molt diverses maneres, però sovint per amagar operacions de crèdit. El comanador fou Bernat Soler, un important prohom de la vila de Santa Coloma de Queralt, cirurgià de professió, de qui coneixem amb gran detall bona part de la seva biografia (Ferragud 2005: ad indicem). Potser el fet que Bernat Soler li prestés diners pot indicar que Bartomeu estava mirant de posicionar-se en algun municipi com 
a contractat. Santa Coloma no era una mala opció. Però ens inclinem a pensar que Tresbens havia albirat una altra font d'inversió. De fet, aquella era una vila dinàmica, on el conreu i l'exportació de safrà s'havien convertit en una font de riquesa clau. Comptava també amb una important comunitat jueva, molt activa en el món del crèdit i d'altres activitats econòmiques (Secall I986). Però també hi havia metges hebreus, com era habitual a qualsevol call constituït (Secall r985). Estigué atret Tresbens per tot aquest context? No ho sabem, però no deixa de resultar d'interès reparar en el fet que fou Cervera, un municipi pròxim i estretament connectat amb Santa Coloma de Queralt (Llobet I982), aquell que intentà la seva contractació uns anys després. Amb tot, Soler fa l'efecte que tenia una forta ascendència sobre el col-lectiu de practicants de la medicina locals, tant físics i cirurgians com apotecaris. La seva influència arribà fins i tot a la generació que el va succeir, ja que va deixar la seva biblioteca a un parell de joves estudiants de medicina. Si Soler tenia tan ben lligat el mercat mèdic de la vila on residia, és difícil pensar que hi hagués lloc per a algú de l'entitat de Tresbens.

En qualsevol cas, el comportament de l'astròleg fou l'habitual entre la classe mitjana a la qual pertanyia. Esmerçar en el luxe, però també iniciar un nou negoci, demanava esforços pecuniaris extraordinaris. Un recurs n'eren les empreses mercantils. El dinamisme del comerç en la Corona d’Aragó era cada vegada més evident, per bé que era Catalunya el territori que en aquell temps en liderava l'empenta. Els límits, però, per al moviment de mercaderies eren diversos. Així, el trànsit lliure es podia veure compromès, a banda de pels perills dels camins insegurs i les prohibicions d'extreure determinats productes, també per les traves impositives. Si es comptava amb el favor reial, però, alguns d'aquests problemes es podien alleugerir.

No foren pocs els professionals de la sanitat que transitaren al món del comerç (Ferragud 2005: 435-468). Aquest fou el cas de Tresbens, que mostrà interessos mercantils en dues ocasions documentades en què es va aprofitar de la intercessió del rei per tirar endavant, amb total llibertat, les seves activitats, sense impediment de les lleis que hi havia en contra. Val a dir que l'activitat mercantil de Tresbens es va desenvolupar en un moment esplèndid de l'economia barcelonina, just unes dècades abans que s’iniciés el procés de declivi i crisi (Carrère 1978).

El I372, l'astròleg va rebre un guiatge o salconduit (custodiam et comandam ac guidaticum) del rei per poder moure's lliurement amb els seus socis Guilhem Durand i el seu fill Joan, de Pàmias, al comtat de Foix (doc. I2), pels territoris de la Corona d'Aragó, amb els individus (factores, negociatores, procuratores et famulos vestros) i mercaderies que l'empresa impliqués. Això sense ser molestats ni punits, evitant així la normativa -segons especifica la lletra del monarca- que llavors impedia aquests intercanvis amb el regne francès. Que Tresbens mantingués una societat mercantil (societas), mecanisme de funcionament habitual entre els mercaders d'aquell temps, és lògic, ja que aquesta servia per a compartir riscs i assegurar guanys, però més quan el comerç no era la seva principal activitat. També hem de remarcar que els seus companys fossin de la regió de la qual ell era originari. Això indica que Tresbens no trencà mai del tot els lligams amb terres occitanes. I també ens convida a pensar que aquella era una societat mercantil que demanava bastant capital humà i pecuniari. Quins productes implicarien aquests intercanvis amb el Llenguadoc, no ho sabem pas. Segons Carrère (1978: 2, 30-43), aquella zona va esdevenir una font de proveïment de cereals i de pastell, matèria primera molt necessària per a la rutilant indústria drapera barcelonina. Per contra, la ciutat comtal aportava en direcció continental un grup molt divers de productes, des dels agraris a espècies i drogues de tota mena, i manufactures variades.

La segona ocasió en què Tresbens va demostrar els seus interessos mercantils s'esdevingué dos anys després. En una carta datada el 23 d'octubre del I374, el duc, a petició de Bartomeu, li donà llicència per traure del regne de València I5O quintars de figues (uns 6.200 quilograms) (doc. 26). La circulació interna i externa d'aquesta fruita solia ser lliure, excepte en determinades conjuntures, com ara durant les guerres, períodes en què se’n limitava l'exportació, ja que eren aliments molt 
apreciats que podien substituir la mancança d'altres. ${ }^{27} \mathrm{I}$ el període $1374-75$, just quan es concedeix el privilegi a Tresbens, amb la pau amb Castella encara sense signar, fou especialment difícil perquè es va viure un temps de grans caresties de blat. El Cerimoniós va permetre llavors una gran mobilitat de figues en direcció a les grans ciutats on la manca d'aliments bàsics era alarmant. L'any I374 havia estat un període especialment fructífer per a la collita de figues al sud del regne de València, $\mathrm{i}$ aquesta fruita esdevingué la moneda de canvi per a vendre-la fora a canvi d'obtenir blats i introduirlos en els territoris de la Corona d'Aragó (Ferrer 200I: 886-888 i 905-9o6).

Aquests afers mercantils degueren ocupar-li més temps i dedicació del que aparentment podríem pensar. En el darrer document del qual tenim constància (doc. 38) de la biografia de l'astròleg, tot just es parla del robatori que va fer el seu servent Pere Draper dels seus libris negociorum suorum clausis et sigillatis. I és que l'art de la mercaderia requeria de registres acurats de la comptabilitat. Des del més humil pagès fins les més sofisticades companyies comercials guardaven papers que servien per a certificar les propietats, i també per a dur amb cura els resultats de petites i grans operacions, dels morosos i de les inversions (Aurell r996: $357^{-35^{8}}$ ).

No sembla que Tresbens s’interessés especialment per les propietats immobles. Era esperable en algú que es movia tant; difícilment hauria pogut gestionar terres, i menys controlar-ne la producció. No obstant això, no va renunciar a pledejar per una heretat en el terme de Pina, prop de Saragossa, en l'any I369 (doc. 9). El plet es va moure contra Marta de Buesa, esposa del notari Bartolomé Ferrando de Maicas. ${ }^{28} \mathrm{El}$ duc Joan ordenà a un jurista saragossà que intervingués en l'assumpte, que no sabem com es va resoldre.

\section{La temptació de Cervera}

Malgrat els evidents beneficis de formar part de la casa reial, un metge podia exercir altres tasques i tenir responsabilitats en el lloc on residia. Ara bé, optar per instal-lar-se en un municipi com a metge pensionat era una altra possibilitat, molt menys lucrativa, aparentment, i amb unes exigències que potser no eren del gust d'un professional de la medicina de gran prestigi. El ben cert és que Tresbens tingué una bona oportunitat per donar aquest pas en un escenari bastant propici per als negocis i ben protegit per la Corona.

En la via de comunicació entre Barcelona i Lleida, que conduïa a Aragó i a l’interior de la península Ibèrica, la vila de Cervera havia esdevingut un centre d'especial importància geoestratègica i política ja en temps de Tresbens (Verdés 2004: I6-I9), i n'és un signe inequívoc que durant la primera meitat del segle XIV fou un dels deu nuclis més poblats de Catalunya. A meitat de la centúria, en el seu període de màxima expansió demogràfica i urbanística, hi devien viure unes 6.ooo ànimes. Entre I359 i I379 es va produir, però, una despoblació progressiva, provocada per les successives onades epidèmiques i les guerres, a la qual les autoritats locals miraren de posar fre, amb la col-laboració de la Corona.

La importància econòmica de Cervera estigué en consonància amb el seu pes polític. Així, des

\footnotetext{
27. Malgrat les apreciacions dels metges, que consideraven les fruites en tant que medicament més que com aliment, i que veien amb reserves la seva presència en l’alimentació, aquelles varen ser consumides àmpliament (García 2OI3). Les fruites ocupaven un lloc dins el regiment preservatiu de la salut, ja que podien corregir algunes situacions derivades de la climatologia. Molt recomanades eren a l'estiu, quan comportaven nombrosos beneficis a l'organisme. Les figues seques són una de les fruites esmentades en el Regiment de sanitat d'Arnau de Vilanova (Gil I996: 224-225; Carré 2OI7: $\left.2 \mathrm{I} 5^{-2} 33\right)$.

28. No s’ha conservat documentació d'aquest notari en l’Archivo Histórico de Protocolos de Zaragoza.
} 
del segle XIII s'hi celebrava mercat, i des dels inicis del XIV rebé privilegi per a tenir fira pròpia, $\mathrm{i}$ també per a mercadejar amb totes les viles i ciutats del Principat (Verdés 2004: 23; Turull r99o: 57). Cervera destacà per la producció vitivinícola, però sobretot fou un gran centre de producció cerealícola, i es convertí en l'autèntic graner de Catalunya. L’aprofitament cada vegada més eficaç de les aigües estigué relacionat amb aquesta productivitat. A això se sumava la producció de safrà, cabdal per a la comarca, i esdevindria centre d'adquisició del producte per a companyies europees que el redistribuïen pel continent (Verdés 20OI). Quant a la manufactura, el tèxtil i el treball amb pells es va desenvolupar, per bé que no arribà a tenir més impacte que el regional (Turull I990: 596o). L'elevat nombre de notaris i mercaders que habitaven la vila entre i36o i i379, manifesta la seva dinàmica i l'important grau de riquesa. Doncs bé, d'aquest escenari, atractiu sens dubte, Tresbens rebé una interessant oferta laboral.

El 24 de maig de i372, el Consell municipal de Cervera es va reunir amb els paers per posar remei a un problema que els angoixava: la manca de metge pensionat (doc. I3) (Ferragud 20I8). Com que s'apropava l'estiu, temps en què solien fer-se presents les epidèmies, i veien que calia fer front al risc, varen pensar a fer-se amb els serveis de Pere d'Isovals, un metge que havia estat ja assalariat més de vint anys abans. Se li oferirien cinc anys de contracte a raó de 500 sous anuals, com havia estat habitual, i una exempció d’impostos. El 3 o de juliol de I372 es varen reunir de nou les autoritats. Els paers posaren de manifest que a la vila no solament continuaven sense cap metge contractat sinó que tampoc disposaven de cap mestre que regentés l'escola. Explicaven que un metge nouvingut anomenat Berenguer Sabater havia ofert els seus serveis per un salari anual bastant moderat, de I5 lliures (300 sous), més una exempció d’impostos, però que ells no volien acceptar-lo sense que abans no es pronunciés el Consell.

En aquella conjuntura de necessitat de metge i mestre, els síndics de la vila, que eren llavors a Barcelona, havien sabut que Bartomeu de Tresbens també hi era i es mostrava disponible, i pensaren que si li donaven una pensió suficient, segurament aquest s'avindria a oferir els seus serveis als cerverins. Els paers hi apostaren; però, això sí, partint d'una oferta més humil que no el salari de què havien gaudit anteriorment els metges de Cervera. L'oferta es xifrava en Io lliures (200 sous), que es podria augmentar fins a I5 en la negociació, més l'exempció d'impostos. També acordaren que es negociaria el temps de durada del contracte. Crida l'atenció la rebaixa salarial, segurament relacionada amb el descens demogràfic i el consegüent empobriment de la vila. Cal insistir que la situació aquell estiu era dramàtica. La pesta havia fet acte de presència, com ho demostra el fet que el dia de sant Miquel s'hagués fet una processó a la vila per treure's de sobre el mal pestilent (Llobet I983: 39). Fins i tot els síndics que s'havien traslladat a buscar metge havien caigut malalts, i la vila encara oferia exempcions fiscals per als barbers que volguessin fer-hi residència, ja que també n’hi havia escassesa i eren el perfil mèdic més a l'abast per a la majoria de la població (Canela i986: 56 ).

Passats quasi dos mesos, el consell es va tornar a reunir amb els paers. De Barcelona estant, els síndics explicaren la marxa de les negociacions amb Bartomeu. Les peticions exigides pel físic eren bastant més elevades que no havien pensat: 50 lliures (I.Ooo sous) per un període de I 5 anys o per a tota la seva vida, una exempció total d'impostos i una casa de franc. Sens dubte, les autoritats degueren quedar espantades, ja que les condicions de Tresbens ultrapassaven en molt el que havien estat acostumats a satisfer, i a més el físic reial es volia assegurar un contracte per un període inusualment llarg. Cal pensar que un madur Tresbens, que aleshores devia comptar uns 55 anys, pogué preparar-se el terreny per a finalitzar els seus dies en una vila que oferia bones oportunitats de guany, amb la medicina i amb el comerç, apartada de Barcelona però ben comunicada, cosa que li podia facilitar de continuar al servei de la cort. No era estrany que els físics reials adoptessin aquesta opció de retirada al rerepaís en moments de la seva vida, sobretot en l'ocàs, i si podia ser, com a senyors feudals amb els seus propis vassalls. Així, Jaume d'Avinyó, cirurgià de Pere el Cerimoniós, 
i amb forta influència en la ciutat de València, era posseïdor d'una alqueria anomenada Vilella, en terme de Sueca, des de I368 (Ferragud 2005: 404-405). El també físic del Cerimoniós, el gironí Guillem Colteller, acabaria, després d'un procés d'adquisicions i donacions reials, per esdevenir senyor d'Esponellà i el seu castell, prop de Banyoles (Ferragud 2005: 523-525). Gabriel Garcia, metge de la reina Maria, esposa d'Alfons el Magnànim, passà els últims anys de la seva vida retirat a Vinalesa, un petit llogaret al nord de València que havia comprat, i on va morir cap a I46I. Afectat per la gota, el metge fou requerit per atendre la reina en la seva dar rera malaltia (Mur I9I3: I4).

Les autoritats, preocupades pel fet que una vila de la seva categoria no tingués un "sollemniall metge" i seduïts per la fama de Tresbens, de qui es deia "sie bon metge e gran astròlech", acordaren complaure'l en totes les seves peticions. I, si no hi havia alternativa, s'avindrien a pagar-li el lloguer de la casa. Això sí, la pensió la hi donaven preferentment a Io anys, i si no hi havia altra opció, a I5. Encara, un parell de consellers insistiren en el fet que si Pere d'Isovals podia incorporar-s'hi més aviat, que no continuessin les negociacions amb Tresbens.

$\mathrm{El} 3$ d'octubre es tornaren a reunir. Certament, Tresbens podia resultar molt onerós per a l'erari públic, i no tots estaven d'acord amb la seva contractació. A més, havien escrit a Pere d'Isovals, que havia respost que si l'esperaven un any, vindria. La prova que els honoraris sol-licitats per l'astròleg eren realment un problema és que el consell envià dos dels seus membres a negociar amb Tresbens una reducció del temps de durada del contracte, a un màxim de 5 anys, i una rebaixa del salari.

El 22 d'octubre, aplegats de nou, llegiren una carta enviada per un dels síndics desplaçats a Barcelona. La darrera oferta de Tresbens continuava sent inassequible per al Consell de Cervera: Ioo florins anuals per un període de Io anys. Després de reflexionar-hi, s'acordà de contestar-li que li seria donada una pensió de 5 o lliures per a Io anys, però hi hagué l'oposició de vuit consellers, que manifestaren que tot plegat era una quantitat molt alta i per un període també massa llarg.

Pel que sembla, les negociacions finalitzaren en aquest punt i el contracte mai es va arribar a materialitzar. El febrer de I373, el consell acordava contractar un franciscà anomenat Guillem Arnau, amb reputació de bon metge, segons afirmaven, per una quantitat de i5o florins anuals, que, com es veu, encara superava la petició de Tresbens, per bé que el contracte degué ser curt, ja que en I377 ja buscaven un altre físic per contractar (Llobet I990: II7).

Les exigències del metge-astròleg havien estat excessives, per més que la seva fama hagués suposat un motiu més d'orgull per als prohoms cerverins i una garantia de tenir un bon metge en temps de pesta. Com manifesta Michael McVaugh, en aquestes contractacions individuals es percep una tensió, que motivava la fluctuació de la seva quantia, depenent de si la ciutat o el metge estaven més o menys ansiosos per emplenar la vacant (McVaugh 1993: 199). La voluntat de tenir cobertes les necessitats sanitàries i de tenir un conseller i metge ben satisfactori hi jugaven un paper determinant. Com s'evidencià en el cas de Cervera, alguns apostaren clarament pel prestigi de l'astròleg reial, mentre que altres miraren de salvaguardar els fons municipals i buscar algun metge-mestre més econòmic. Tresbens va veure una oportunitat òptima d'assentar-se a Cervera per un llarg període i aprofitant la conjuntura pestífera; la por, en definitiva, però també la confiança general en la medicina, foren factors que li van fer pensar que podia esprémer les arques municipals. No va reeixir en la jugada, i potser no hi tenia gaire interès perquè devia ser conscient de les abusives peticions que havia fet. Amb tot, un parell d'anys després, Tresbens seria citat a Cervera pel rei per alguns afers que desconeixem (doc. 28). Només una trobada circumstancial amb el que hauria pogut ser un bon destí. 


\section{${ }_{7}$ Conclusions: una carrera a l'ombra del poder}

A diferència de la seva obra conservada, gairebé exclusivament astrològica, l'anàlisi de la documentació que aquí donem a conèixer ens permet una aproximació més polièdrica a la figura de Bartomeu de Tresbens, no solament a la seva doble faceta de metge i astròleg, sinó també a la seva relació amb la família reial, a les seves activitats econòmiques i a certs aspectes biogràfics. Si tenim en compte l'interès del rei Pere i del seu primogènit Joan tant per la medicina -el manteniment de la salut de la família reial i la regulació de la professió mèdica com a base de la sanitat dels seus regnes- com per l'astrologia, un personatge amb el doble perfil que oferia Tresbens estava en la millor situació per promocionar-se al servei de la Corona. En l'obra i la documentació trobem pistes de com un graduat universitari medieval podia utilitzar els seus sabers per obrir-se camí i guanyarse una notable posició social i econòmica a l'empara dels poderosos. Tanmateix, la proximitat a la família reial, si bé li proporcionava oportunitats per enriquir-se, una certa influència i un gran prestigi, també l'exposava als vaivens i als atzars de les necessitats del poder i dels conflictes de la cort. Així, la Corona gratificà amb generositat un servidor proper com Tresbens, tant per l'atenció mèdica a la família reial o en campanya militar com per la seva obra astrològica o certes prediccions fonamentades en els astres. Les recompenses no consistien tan sols en la remuneració habitual o la gratificació ocasional directes, sinó també en un favor reial que atorgava permisos excepcionals per fer negocis, pressionava les autoritats locals o intervenia en plets, així com en un prestigi que donava impuls a la promoció professional. Naturalment, tot això no era a canvi de res. Tots aquests avantatges podien posar-se en risc si el servidor suscitava sospites sobre la seva fidelitat al monarca o si s'involucrava en un episodi de lluita pel poder. Probablement, una raó d'aquesta mena fou la que va fer perdre a Tresbens la seva posició privilegiada.

\section{Agraïments}

Volem agrair molt encaridament a Lluís Cifuentes (Universitat de Barcelona) la seva col-laboració en la revisió acurada dels documents editats en apèndix, així com pels comentaris al text. Al mateix Lluís Cifuentes i a Xavier Lamuela (Universitat de Girona), l'ajuda en la descoberta dels orígens de Tresbens. Agraïm també la informació proporcionada per Asunción Blasco Martínez (Universidad de Zaragoza) i Raúl Villagrasa Elías (Instituto de Historia, CSIC) pel seu coneixement dels arxius de Saragossa. 


\section{Obres citades}

Aurell, Jaume. 1996. Els mercaders catalans al quatre-cents: mutació de valors i procés d'aristocratització a Barcelona (1370-1470) (Lleida: Pagès)

Avenoza, Gemma (dir.). 1989-2018. BITECA. Bibliografia de textos catalans antics (Berkeley: University of California) <https://tinyurl.com/mzuqlzj> [accés I8-7-2OI8]

Badia, Lola (ed.). 1999. Bernat Metge Lo somni (Barcelona: Quaderns Crema).

Belenguer, Ernest. 20I5. Vida i regnat de Pere el Cerimoniós (1319-1387) (Lleida: Pagès)

Boudet, Jean-Patrice. 2006. Entre science et nigromance: Astrologie, divination et magie dans l'Occident médiéval (XIIe-XVe siècle) (Paris: Publications de la Sorbonne)

Campo Gutiérrez, Ana del. 2007. 'Catalina del Hospital: ciudadana de prestigio', in Vidas de mujeres del Renacimiento, ed. by Blanca Garí (Barcelona: Universitat de Barcelona), pp. 23-40

Camps Surroca, Manuel. 1998. 'Nadal Lembri, mestre en Arts i Medicina, professor de l'Estudi General de Lleida', Gimbernat, 30: III-II7 <https://tinyurl.com/y83ke662 $>$

Canela i Garayoa, Montserrat. I986. 'Cervera I333-I384: pestes, fams i guerres’, Miscel·lània Cerverina, 4: $55^{-66}<\underline{\text { https: } / / \text { tinyurl.com/yzjnoyqn }>}$

Carré, Antònia (ed.). 20I7. Arnau de Vilanova Regiment de sanitat per al rei d’Aragó. Aforismes de la memòria (Barcelona: Universitat de Barcelona)

Carrère, Claude. 1978. Barcelona 1380-1462: un centre econòmic en època de crisi, 2 vols (Barcelona: Curial)

Chabàs, Josep. 1992. L'Astronomia' de Jacob ben David Bonjorn (Barcelona: Institut d'Estudis Catalans)

Chabàs, Josep. 2004. 'L'activitat astronòmica a l'època del rei Pere (segle XIV)', in La ciència en la història dels Paüsos Catalans, ed. by Joan Vernet and Ramon Parés (València: Institut d'Estudis Catalans; Universitat de València), I: Dels àrabs al Renaixement, 483-5I4

Cifuentes i Comamala, Lluís. I993. Medicina i guerra a l'Europa baix-medieval: la sanitat i la participació dels seus professionals en les expedicions militars de la Corona d'Aragó (1309-1355), (doctoral thesis, Universitat Autònoma de Barcelona)

Cifuentes i Comamala, Lluís. 1998. 'Estudi introductori', in Arnaldi de Villanova Opera Medica Omnia, X.2: Regimen Almarie, ed. by Michael R. McVaugh (Barcelona: Universitat de Barcelona)

Cifuentes i Comamala, Lluís. 2006. La ciència en català a l'Edat Mitjana i el Renaixement, 2nd edn (Barcelona: Universitat de Barcelona; Palma: Universitat de les Illes Balears)

Cifuentes i Comamala, Lluís (coord.). 2012-2018. Sciència.cat DB (Barcelona, Universitat de Barcelona) $<$ https://tinyurl.com/q3e748k $>$ [accessed I8-7-2018]

Cortes de los antiguos reinos de Aragón y de Valencia y principado de Cataluña. I896 (Madrid: Real Academia de la Historia), II

Collard, Franck. 2003. Le Crime de poison au Moyen Âge (Paris: PUF)

Ferragud, Carmel. 2005. Medicina i promoció social a la Baixa Edat Mitjana (Corona d'Aragó, 1350-1410) (Madrid: CSIC) 
Ferragud, Carmel. 20II. 'El metge sota sospita: actuació mèdica en els testimonis pericials a ferits davant la cort del justícia criminal de la ciutat de València (I396)', Recerques, 62: 69-94 < $\underline{\text { https:// }}$ tinyurl.com/yaevuzbo $>$

Ferragud, Carmel. 20I6. 'Los peritajes médicos en la Valencia bajomedieval: los casos de envenenamiento', Dynamis: $36 . \mathrm{I}$ : II9-I4I $<\underline{\text { http://dx.doi.org/IO.432I/SO2II- }}$ $25362016000100006>$

Ferragud, Carmel. 20I8. 'Bartomeu de Tresbens, físic i astròleg del rei Pere el Cerimoniós i l'infant

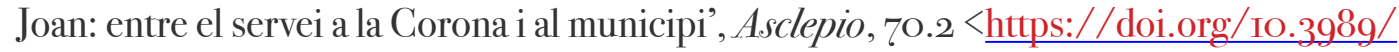
asclepio.2OI8.II>

Ferrer i Mallol, Maria Teresa. 200I. 'Fruita seca i assecada, una especialitat de l'àrea econòmica catalana-valenciana-balear', Anuario de Estudios Medievales, 3. org/IO.3989/aem.200I.v3I.i2.272>

Font i Rius, Josep Maria. I988. Constitucions de Catalunya: incunable de 495 (Barcelona: Generalitat de Catalunya)

Colón, Germà; Garcia, Arcadi (ed.). r999. Furs de València, Els Nostres Clàssics, Col-lecció A, I36 (Barcelona: Barcino), VIII

García Ballester, Luis, McVaugh, Michael R.; Rubio Vela, Agustín. 1989. Medical Licensing and Learning in Fourteenth-Century Valencia (Philadelphia: The American Philosophical Society)

García Marsilla, Juan Vicente. 2002. Vivir a crédito en la Valencia medieval: de los orígenes del sistema censal al endeutamiento del municipio (Valencia: Universitat de València)

Gil-Sotres, Pedro. I999. 'Estudi introductori', in Arnaldi de Villanova opera medica omnia, dir. by Luis García Ballester, Javier A. Paniagua and Michael R. McVaugh (Barcelona: Universitat de Barcelona; Fundació Noguera), X.I: Regimen sanitatis ad regem Aragonum, ed. by Luis García Ballester and Michael R. McVaugh

Gimeno, Francisco M.; Gozalbo, Daniel; Trenchs, Josep. 2009. Ordinacions de la Casa i Cort de Pere el Cerimoniós (València: Universitat de València)

Giralt, Sebastià. 20I7. 'Drawing from the Marrow of the Authors of Astrology: The Sources of Bartomeu de Tresbens, Astrologer to King Pere the Ceremonious of Aragon', in De Frédéric II à Rodolphe II: Astrologie, divination et magie dans les cours (XIIIe-XVIIe siëcle), ed. by Jean-Patrice Boudet, Martine Ostorero and Agostino Paravicini Bagliani (Florence: SISMEL-Edizioni del Galluzzo), pp. 7'-96

Giralt, Sebastià. 20i8a. 'Astrology in the Service of the Crown: Bartomeu de Tresbens, Physician and Astrologer to King Pere the Ceremonious of Aragon', Journal of Medieval History, 44.I: I-26 $<\underline{\text { https://doi.org/IO.IO80/O304418I.20I7.I397534 }}$

Giralt, Sebastià. 20IOb. 'Astrologia per a la recerca de tresors: el Libel d'investigació de tresors de Bartomeu de Tresbens', eHumanista/IVITRA, I4: 76I-793 < https://tinyurl.com/yz7gvppp $>$

Gómez Rojo, María E. 20o6. 'Línies sobre la reglamentació historicojurídica i la consideració social de l'exercici de la professió d'advocat en l'àmbit territorial catalanovalencià en algunes fonts jurídiques medievals en relació amb el pensament de Francesc Eiximenis', Revista de Dret Històric Català, 6: 235-257 〈https://doi.org/IO.2436/20.3004.OI.I2 $>$

González Antón, Luis. 1975. Las Uniones aragonesas y las Cortes del Reino (1283-1301), 2 vols (Zaragoza: CSIC) 
Javierre Mur, Áurea L. 193o. Matha de Armanyach, duquesa de Gerona (Madrid: Tipografía de Archivos)

Llobet i Portella, Josep Maria. I982. 'Relacions entre Cervera i Santa Coloma de Queralt (s. XVXVII)', Recerques. Terres de Ponent, 3: 49-54

Llobet i Portella, Josep Maria. I983. 'Les epidèmies a Cervera durant l’Edat Mitjana', Miscel-lània Cerverina, I: 39-46 < https://tinyurl.com/y8cakkz3>

Llobet i Portella, Josep Maria. r99o. 'Els metges a Cervera durant els segles XIV i XV' Gimbernat, I3: II5-I40 < https://tinyurl.com/y6u8kg2g $>$

López de Meneses, Amada. 1952. 'Florilegio documental del reinado de Pedro IV de Aragón', Cuadernos de Historia de España, I7: I67-176

Macías, Cristóbal. 20I6. 'Algunas consideraciones sobre la astrología en el Reino de Aragón’, eHumanista, IO: 456-92 <https://tinyurl.com/y8ahase 4 >

Madurell i Marimon, Josep Maria. I936. 'El Palau Reial Major de Barcelona: recull de notes històriques', Analecta Sacra Tarraconensia, I2: 49I-518 <https://tinyurl.com/y8uldlux $>$

Martin, Georges. 2007. Histoire et généalogie de la maison de Lévis (Lyon: G. Martin).

McVaugh, Michael R. 1993. Medicine Before the Plague: Practitioners and their Patients in the Crown of Aragon (1285-1345) (Cambridge: Cambridge University Press)

Millàs Vallicrosa, Josep Maria. I962. Las 'Tablas astronómicas' del Rey Don Pedro el Ceremonioso (Madrid: CSIC; Barcelona: Asociación para la Historia de la Ciencia Española)

Moulinier-Brogi, Laurence. 20I2. L'Uroscopie au Moyen Age: 'Lire dans un verre la nature de l'homme'(Paris: Champion)

Muñoz Gómez, Víctor. 20I5. 'La candidatura al trono del infante Fernando de Antequera', in Martí l'Humà, el darrer rei de la dinastia de Barcelona (1396-1410): l'Interregne i el Compromís de Casp, ed. by Maria Teresa Ferrer i Mallol (Barcelona: Institut d'Estudis Catalans), pp. 877-897

Mur Sancho, Jaime. I9I3. Recuerdo apologético de Gabriel García, maestro en medicina, archiatro de los reyes de Aragón (Valencia: Tipografía Moderna)

Roca, Josep Maria. I922. Maestre Guillem Colteller, metge dels reys d'Aragó Pere III i Joan I (Barcelona: Imp. Badia)

Roca, Josep Maria. 1923. 'Notes medicals històriques', Anals de Ciències Mèdiques, I7.8: 26I-265

Rosa Cubo, Cristina de la. 20oo. Summa medicinae (Mad. Esc. M. II. 17): estudio y edición crítica (doctoral thesis, Universidad de Valladolid)

Rubió i Lluch, Antoni. I908-I92I. Documents per l'historia de la cultura catalana mig-eval, 2 vols (Barcelona: Institut d'Estudis Catalans) <https://tinyurl.com/yzqnzegu $>$

Ryan, Michael R. 20II. A Kingdom of Stargazers: Astrology and Authority in the Late Medieval Crown of Aragon (Ithaca, NY: Cornell University Press) <https://doi.org/IO.759I/ cornell/978080I449840.00I.000I>

Sáiz Serrano, Jorge. 2008. Caballeros del rey: nobleza y guerra en el reinado de Alfonso el Magnánimo (Valencia: Universitat de València)

Sarasa, Esteban. 20I5. 'Las Cortes de Aragón en el reinado de Martín el Humano', in Martíl'Humà, el darrer rei de la dinastia de Barcelona (1396-1410): I'Interregne i el Compromís de Casp, ed. by 
Maria Teresa Ferrer i Mallol (Barcelona: Institut d’Estudis Catalans), pp. I99-206

Secall i Güell, Gabriel. 1985. 'Metges i cirurgians hebreus a Santa Coloma de Queralt (segles XIVxv)', Gimbernat, 4: 339-348 <https://tinyurl.com/yb6n7syf>

Secall i Güell, Gabriel. 1986. La comunitat hebrea de Santa Coloma de Queralt (Tarragona: Diputació Provincial de Tarragona),

Soldevila, Ferran (ed.) 20I4. Les quatre grans cròniques, Iv: Crònica de Pere III el Cerimoniós, ed. by Josep Massot i Muntaner Jordi Bruguera and Maria Teresa Ferrer i Mallol (Barcelona: Institut d'Estudis Catalans)

Torre y del Cerro, Antonio de la; Rubió Balaguer, Jordi. 1971. Documentos para la historia de la Universidad de Barcelona, I: Preliminares (1289-1451) (Barcelona: Universitat de Barcelona)

Trenchs, Josep. 2OII. Documents de Cancelleria i de Mestre Racional sobre la cultura catalana medieval, ed. by Maria Teresa Ferrer i Mallol et al. (Barcelona: Institut d'Estudis Catalans)

Tuixans, Joaquín. I926. 'El Mestre en Medeçina En Bertomeu de Tresbens', Las Provincias, I9 d'agost de 1926

Turull, Max. 1990. La configuració jurídica del municipi Baix-Medieval: règim municipal i fiscalitat a Cervera entre 1182-143o (Barcelona: Fundació Noguera; Lleida: Pagès)

Verdés, Pere. 2004. 'Per ço que la vila no vage a perdició': la gestió del deute públic en un municipi català (Cervera, 1387-1516) (Barcelona: CSIC)

Vernet, Joan; Romano, David (ed.). I957-I958. Bartomeu de Tresbens Tractat d'astrologia (Barcelona: Biblioteca Catalana d'Obres Antigues)

Véronèse, Julien. 20I7. 'Nicolas Eymerich et l'astrologie à la cour d'Aragon', in De Frédéric II à Rodolphe II: Astrologie, divination et magie dans les cours (XIIIe-XVIIe siècle), ed. by Jean-Patrice Boudet, Marine Ostorero and Agostino Paravicini Bagliani, Micrologus Library, 85 (Florence: SISMEL-Edizioni del Galluzzo), pp. 97-I55

Wittlin, Curt et al. (ed.). r986. Francesc Eiximenis, Dotzè llibre del Crestià, 2-I (Girona: Col-legi Universitari de Girona; Diputació de Girona)

Zurita, Jerónimo.I967-I985. Anales de la Corona de Aragón, ed. by Ángel Canellas López (Zaragoza: CSIC-Institución “Fernando el Católico”)

9.I Abreviatures utilitzades

ACA: Arxiu de la Corona d'Aragó

AHCB: Arxiu Històric de la Ciutat de Barcelona

C: Cancelleria reial

RP: Reial Patrimoni

MR: Mestre racional

reg.: registre

vol.: volum

f./ff.: foli/folis 


\title{
Io Apèndix: Diplomatari. Documentació conservada sobre Bartomeu de Tresbens
}

\author{
IO.I Criteris d'edició
}

Oferim aquíl'edició de tots els documents coneguts sobre Bartomeu de Tresbens. Tots ells, inclosos aquells que ja havien estat publicats anteriorment, han estat editats per nosaltres, gairebé sempre a partir de les còpies fotogràfiques proporcionades pels arxius en què es conserven, excepte en el cas del document I, del qual hem pogut consultar l'original. Hem mantingut les grafies originals dels documents. Tanmateix, seguint els criteris habituals d'edició de textos medievals, hem adoptat la distinció moderna d'u/v en el documents llatins i, en els catalans, hem aplicat la distinció moderna d'u/v i i/j, hem accentuat, hem posat dièresis i hem utilitzat l'apòstrof per indicar les elisions que actualment es marquen amb aquest signe, el punt volat per separar les formes aglutinades que avui s'escriuen separades i els guionets per a les formes enclítiques pronominals. També hem regularitzat l'ús de les majúscules. La puntuació segueix les normes actuals, inclosa la supressió dels punts que limiten els numerals.

Abreviatures i signes:

exp.: text cancel-lat en el document

scripsi: correcció dels editors

s. l.: escrit en interlineat

[ ]: paraules i les lletres afegides pels editors

| |: text disposat en una columna

|: text disposat en diverses columnes

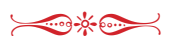

$\min$

I359, març 22. Barcelona.

Acta notarial de l'examen de mestre Jaume de Pallars, realitzat per metges de Barcelona d'acord amb les disposicions instaurades pel rei Alfons el Benigne, davant els consellers de la ciutat, i amb el testimoni de cirurgians i mercaders. Els metges examinadors, entre els quals hi ha Tresbens, declaren apte el candidat i aquest fa el jurament d'exercir les seves tasques professionals lleialment.

AHCB, Estudi General, CC - XVIII - 9, I.

Ed.: Torre-Rubió 1971: 38-42, núm. 22.

Noverint universi quod cum iuxta tenorem cuiusdam capituli editi in Curia Montissoni per serenissimum dominum Alffonsum primum, regem Aragonum, memorie recolende, celebrata, aliquis medicus $\mathrm{s}^{\mathrm{a}} \mathrm{uti}$ nequeat artem medicine ${ }^{\mathrm{b}}$ donec examinatus fuerit per probos homines uniuscuiusque loci simul cum aliis medicis ${ }^{\mathrm{c}}$, et quod illi qui electi vel approbati fuerint iurent, in posse vicarii vel baiuli et predictorum proborum hominum dicti loci, quod fideliter se habebunt in medicamentis, in visitacionibus, in dissuspitacionibus et in aliis ad ipsam artem seu scienciam pertinentibus quovis modo. Idcirco die veneris vicesima secunda die marcii anno a Nativitate Domini MCCCL nono, paulo post pulsacionem terciarum eiusdem diey, in presencia honorabilium 
virorum Iacobi March, Eymerici de Usay, Raymundi de Sancto Clemente, Guillermi de Laceria et Iacobi de Gualbis, consiliariorum hoc anno civitatis Barchinone, in quadam casa inferiori hospicii quod ego, Simon de Ruvira, notarius Barchinone, habeo in civitate Barchinone iuxta ecclesias Sancti Iacobi et Sancti Michelis, personaliter residencium, et in presencia mei, dicti Simonis de Ruvira, auctoritate regia notarii publici Barchinone et scriptoris Consilii dicte civitatis, et in presencia venerabilium ${ }^{\mathrm{d}}$ Ioannis Serra, Petri Otgerii et Ffrancisci de Orto, mercatoris ${ }^{\mathrm{e}}$, ac Francisci de Manso, Bernardi Camos et Petri Andree, cirurgicorum civium Barchinone, testium ad hec specialiter vocatorum, venerabiles et discreti Petrus Ros, Raymundus de Teseracho et Bartholomeus de Tribusbonis, magistri in artibus et medicina, et Arnaldus Germani, magister in medicina, qui ad examinandum magistrum Iacobum de Pallars, medicum seuf ffisicum, per venerabilem Nicholaum de Ruvira, locumtenentem honorabilis Ffrancisci de Togoriis, militis, vicarii Barchinone et Vallensis absentis, et honorabiles consiliarios supradictos fuerunt assignati, constituti personaliter intus hospicium supradictum in casa scilicet supradicta, prestito per eos iuramento ad sancta Dei quatuor ${ }^{g}$ Evangelia quod super examinacione huiusmodi fideliter et legaliter se haberent, examinaverunt preffatum magistrum Iacobum de Pallars ibidemex hac causa personaliter constitutum de arte seu sciencia medicine seu fisice et de suficiencia seu abtitudine quam habet in arte seu sciencia supradicta, faciendo eidem magistro lacobo de Pallars plurimas questiones, argumenta et alia que ipsis ad noscendam ideoneitatem, sufficienciam vel abtitudinem ipsius magistri lacobi fieri videbantur. Quibus peractis auditisque et intellectis per eos responsionibus per ipsum magistrum Iacobum Pallars factis ad ea que per dictos venerabiles et discretos Petrum Ros, Raymundum de Teseracho, Bartholomeum de Tribusbonis et Arnaldum Germani ab ipso in et super dicta scilicet arte seu sciencia medicine seu fisice petita fuerant et quesita, iidem venerabiles Petrus Ros $^{\mathrm{k}}$, Raymundus de Teseracho, Bartholomeus de Tribusbonis et Arnaldus Germani dixerunt, in presencia ipsorum venerabilium consiliariorum, qui predictis omnibus et singulis, ut predicitur, affuerunt, et in presencia mei, dicti notarii, et testium predictorum ${ }^{1}$, quod ipsi invenerant iamdictum magistrum Iacobum de Pallars sufficientem, idoneum, practicum atque aptum ${ }^{\mathrm{m}}$ in dicta arte seu sciencia medicine seu ${ }^{\mathrm{n}}$ fisice et in usu et exercicio eiusdem artis ${ }^{\circ}$. Postquam incontinenti sine aliquo temporis intervallo in presencia mei, dicti notarii, et testium predictorum et presentibus etiam ad hoc predictis venerabilibus Petro Ros, Raymundo de Teseracho, Bartholomeo de Tribusbonis, magistris in artibus et in medicina, et Arnaldo Germani, magistro in medicina ${ }^{\mathrm{p}}$, qui ad examinacionem huiusmodi electi seu assignati extiterant, ut est dictum, iamdictus magister Iacobus de Pallars iuravit ad sancta Dei evangelia in posse dicti venerabilis Nicholai de Ruvira, locumtenentis vicarii supradicti, et venerabilium consiliariorum predictorum quod ipse bene, fideliter et legaliter se habebit in medicamentis, in visitacionibus et dissuspitacionibus et in aliis ad ipsam artem seu scienciam pertinentibus quovis modo. Quibusquidem omnibus et singulis supradictis sic processis et factis, incontinenti iamdictus magister Iacobus de Pallars volens, ut dixit, quod appareat de examinacione predicta que de eo hodie, ut premititur, facta fuit et, ut tucius deinceps uti valeat arte seu sciencia supradicta, peciit in presencia dictorum venerabilium consiliariorum de predictis omnibus sibi fieri publicum instrumentum per me, notarium supradictum. Et confestim dicti venerabiles consiliarii voluerunt et requisiverunt per me, eundem notarium et scriptorem, ut appareat de examinacione predicta de predicto magistro Iacobo de Pallars, ut supra patet facta, et ut ipse Iacobus de Pallars tanquam examinatus libere et tute uti possit artem seu scienciam supradictam, eidem Iacobo de Pallars hoc presens testimoniale instrumentum fieri sigilloque fieri sigilloque Consilii dicte civitatis appendicio comuniri.

Acta sunt hec die, hora, anno et loco predictis, presente me, dicto notario, et presentibus eciam testibus supradictis. 
(a) exp.exp. vel cirurgicus (b) exp. fisice vel ciurgice (c) exp. vel cirurgicis (d) exp. Petri Otgerii (e) et Ffrancisci de Orto, mercatoris s. l. (f) medicum seu s. l. (g) quatuor s. l. (h) medicine seu s. l. (i) et Arnaldum Germani s. l. (k) exp. cirurgice (l) exp. subscritorum / predictorum s. l. (m) exp. Circa usum et exercicium dicte artis necnon ad practicandum, disuspitandum, visi[tandum] (n) seu s. l. (o) exp. seu medicine seu ffisice (p) et Arnaldo Germani, magistro in medicina s. $l$.

$\min 2 \pi$

I36o, maig 5. Santa Coloma de Queralt.

El cirurgià Bernat Soler, de Santa Coloma de Queralt, fa procurador Domingo Guillén Andreu, de Saragossa, per recuperar 8 lliures barceloneses que li deu Bartomeu de Tresbens, mestre en arts i en medicina.

ACCB, Protocols notarials, 536 o4 CU2277 (notari Bernat de Muntanyola), f. 34r..

Magister Bernardus Soleri, medicus sirurgicus ville Sancte Columbe, testimonium huius publicum instrumentum, facio procuratorem vos Dominicum Guillelmum Andreu, civem civitatis Cesarauguste, ad petendum et recuperandum octo libras barchinonenses que resta[n]t ad solvendum per magistrum Bartolomeum de Tribusbonis, magistrum in artibus et in medicina, de quantitate XIII librarum terni quas tenebat in mea comanda, dando potestatem augendi et experiendi et apocham faciendi et omnia alia, et promito tunc habere. Testes [hi manquen els noms].

* Agraïm la lectura del professorMateu Rodrigo Lizondo.

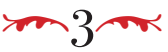

I360, maig I5. Alagón.

El rei Pere ordena al justícia d'Aragó, Johan López de Sesé, a instàncies de Bartomeu de Tresbens, fisic seu, que mani als ferrers de Saragossa que realitzin l'obra que ell els indicarà en el temps que demandarà.

ACA, C, reg. II7I, f. I4r.

Ed.: Rubió 1908-1921: 2, I75, núm. I87.

Don Pedro etcétera. Al amado consellero nuestro Johan López de Sessé, cavallero, justicia de Aragón, o a su lugartenient, salut e dilección. Mandámosvos que, a requisición de maestre Bertolomeu de Tresbienes, maestre en artes e en medicina, físico nuestro, forcedes e costregades de part nuestra aquell o aquellos ferreros de Caragoça que él vos dirá a fer aquella obra que él querrá e en aquellos días, horas e tiempos que ell demandará. Dada en Alagón, dius el nuestro aniello mayor, a XV días de mayo en el anyo de la Natividad de nuestro Senyor MCCCLX. Sigillata.

Dominus rex mandavit mihi Iacobo Conesa.

[Marg. esq.:] Pro curia. 
$4 \pi$

I36I, març 30. Saragossa.

El tresorer del rei, Pere de Màrgens, paga 200 sous jaquesos a mestre Bartomeu de Tresbens, metge de cirurgia (sic) del rei, per la seva quitació ordinària.

ACA, RP, MR, vol. 952, f. $55^{\mathrm{v}}$.

Nota: no ha estat possible transcriure aquest document perquè ara no és permès consultar-lo ni demanar-ne una còpia a causa del seu mal estat de conservació.

$5 \pi$

I36I, abril.

El tresorer del rei, Bernat d'Olzinelles, paga 200 sous jaquesos, equivalents a 18 florins d'or, 8 sous ig diners jaquesos, a mestre Bartomeu de Tresbens («Tresbés»), metge de física de la casa del rei.

ACA, RP, MR, vol. 342 , f. I5or.

Ítem, done a maestre Bertomeu de Tresbés, metge de física de casa del senyor rey, los quals li acorreguí en la ciutat de Saragoça, ab albarà d'escrivà de ració, segons que·n lo dit albarà se conté, que cobre, CC sous jaquesos, los quals, fet cambi per lo racional ab florí d'or a raó de X sous, VII diners, òbol jaquesos per florí, fan - XVIII florins d'or, VIII sous, IX diners jaquesos.

[Marg. esq.:] Albarà d'escrivà de ració en què és fet cambi per lo racional.

$m 6 \pi$

I36I, abril.

El tresorer del rei, Bernat d'Olzinelles, paga 12 florins d'or a mestre Bartomeu de Tresbens

("Tresbés"), metge de física de la casa del rei, per la seva provisió.

ACA, RP, MR, vol. 342, f. I7ov.

Ítem, done a maestre Berthomeu de Tresbés, metge de ffísica de casa del senyor rey, los quals li acorreguí en la vila de l'Almúnia, ab albarà d'escrivà de ració, en acorriment per sa provisió, segons que.n lo dit albarà se conté, que cobre - XII florins d'or.

[Marg. esq.:] Albarà d'escrivà de ració. 
$\min$

I363, abril.

El tresorer del rei, Bernat d'Olzinelles, paga 116 sous i 8 diners barcelonesos al metge de física de la casa del rei mestre Bartomeu de Tresbens ("Tresbés") per la seva quitació ordinària.

ACA, RP, MR, vol. 346 , f. пIIV.

Ítem, done a maestre Barthomeu de Tresbés, maestre de ffísica de casa del senyor rey, los quals li acorreguí en lo loch de Monçó ab lo present albarà lo dia e any dejús scrit en acorriment de sa quitació, segons que·n lo dit albarà se conté, que cobre, $\mathrm{C}$ sous jaquesos, los quals, fet cambi ab barcelonesos, a raó de III sous, IIII diners més per lliura de jaquesos, fan - CXVI sous, VIII diners barcelonesos.

[Marg. esq.:] Albarà d'escrivà de ració.

$\operatorname{mon}$

I363, octubre I. Barbastre.

El rei Pere demana al justícia d'Aragó i conseller seu, Domingo Cerdán, que obeeixi el sobreseïment de sis mesos que ha ordenat respecte de l'execució dels béns que pretenia fer contra els veïns de Saragossa Ferrando López de Sesé i Johan d'Arcayna, per una quantitat que manllevaren al físic Bartomeu de Tresbens.

ACA, C, reg. II9I, ff. 53'v-532r .

Petrus, et cetera, dilecto consiliario nostro Dominico Cerdani, militi, iusticie Aragonis, vel eius locum tenenti ceterisque officialibus nostris ad quos subscripta pertinere noscantur, salutem et dilectionem. Cum nos, in execucione quam facitis seu facere nitimini contra fideles nostros Fferdinadum Luppi de Sesse et Iohannem de Arcayne, vicinos Cesarauguste, pretextu certe quantitatis pro qua magistrum Bartholomeum de Tresbes, fisicum, manulevaverant a posse vestri, certis causis supersederi providerimus et velimus hinc ad sex menses proxime venturos, pro quibus ipsis terminum de tornando in posse vestro, dictum magistrum Bartholomeum prorogandum duximus cum presenti. Idcirco vobis dicimus et expresse mandamus quatenus supersedimentum et prorogacionem huiusmodi firmam habeatis et observatis per totum dictum tempus et non contraveniatis aliqua ratione. Data Barbastri, sub nostro sigillo secreto, prima die octobris anno a Nativitate Domini ${ }^{\circ}{ }^{\circ} C_{C C}{ }^{\circ} \mathrm{LX}^{\circ}$ tercio. Petrus, cancellarius.

Bernardus Michelis, mandato regio facto per Petrum Iordanum d'Urries, militem, consiliarium et maiordomum. Probata.

[Marg. esq.:] Bernat Miquel. X sous IIII diners 
$m 9 \pi$

I369, febrer I4. Saragossa.

Linfant Joan s'adreça a Miguel de Capiella, jurista de Saragossa, en relació al plet entre el mestre en arts i medicina Bartomeu de Tresbens i Marta de Buesa, esposa del notari Bartolomé Ferrando de Maicas, i qualsevol altre que afirmi tenir dret sobre unes propietats en disputa, açò és, un heretament en el terme de Pina, que per sentència arbitral fou adjudicat al metge, i li demana que decideixi el que calgui fer sobre aquest assumpte.

ACA, C, reg. I6I9, ff. I7IV-I72r .

Infans Iohannes, et cetera, ffideli nostro Miquaeli de Capella, iurisperito Cesarauguste, salutem et gratiam. Cum nos de causis seu questionibus que vertuntur aut verti sperantur inter Bartholomeum de Tribusbonis, magistrum in artibus [et] in medicina, de domo dicti domini regis, ex una parte, et Martam de Buesa, uxorem Bartholomei Ferdinandi de Maycas, notarii, et quoscumque alios dicentes seu affirmantes se ius habere in et super quibusdam hereditatibus seu possessionibus in loco seu terminis de Pina situatis, que per sententiam arbitralem eidem Bartholomeo de Tribusbonis fuerunt, ut dicitur adiudicata ex altera coniunctim vel divisim et tam in agendo quam defendendo per nos, ex causa cognosci ordinaverimus et velimus. Pro tanto vobis dicimus, comittimus et mandamus quatenus, vocatis evocandis de ipsis causis seu questionibus, cognoscatis et super eis faciatis et decernatis quod de foro et ratione fuerit faciendum procedendo in eisdem breviter, simpliciter, sumarie et de plano sine strepitu iudicii et figura solaque facti veritate atenta, malitiis et difugiis postpositis et reiectis. Quoniam nos vobis super hiis et dependentibus seu emergentibus ed eisdem aut connexis comittimus cum presenti plenarie vices nostras. Data Cesarauguste, XIIII a die decembris, anno a Nativitate Domini millesimo CCC $^{\circ}$ LX $^{\text {o }}$ nono. Lupus de Lor.

Bertrandus de Pinós, ex peticione provisa per Bernardum de Ponte, legum doctorem, consiliarium. Probata. Bernardus.

(a) scripsi: quoscumque.

$m \mathrm{IO} / \pi$

I370, desembre I8. Saragossa.

L’infant Joan mana a Miguel de Capiella, jurista de Saragossa, que intervingui de manera sumària en el plet entre el mestre en arts i en medicina Bartomeu de Tresbens i Martín Pero Peregrín, de Saragossa, i decideixi el que calgui fer sobre aquest assumpte.

ACA, C, reg. I713, f. $73 \mathrm{~V}$

Infans Iohannes, et cetera, ffideli nostro Micheli de Capiella, iurisperito civitatis Cesarauguste, salutem et gratiam. Cum nos de causa seu questione que sub nostro examine incoata extitit inter Bertholomeum de Tribusbonis, in artibus et in medicina professorem, agentem ex parte una, et Martinum Petri Peregrini, civem dicte civitatis ex altera defendentem, rationibus atque causis in 
processu inde agitato expressatis per nos causa ${ }^{\mathrm{a}}$ cognosci providimus et velimus. Pro tanto vobis dicimus, comitimus et mandamus quatenus, notatis evocandis resumptoque processu predicto in eo statu quo est, quem vobis tradi iubimus, de predictis cognoscatis et super eis faciatis et decernatis breviter, simpliciter, sumarie et de plano absque strepitu et figura iudicii solaque facti veritate attenta, malitiis et difugiis omnibus retroiectis quod de foro et ratione fuerit faciendum. Quoniam nos vobis in et super premissis omnibus et singulis incidentibus et dependentibus seu emergentibus ex eisdem quomodolibet ac connexis vices nostras plenarie comitimus cum presenti. Data Cesarauguste, XVIII ${ }^{a}$ die decembris anno a Nativitate Domini millesimo CCC ${ }^{\circ}$ LXX $^{\circ}$. Franciscus Oliverii.

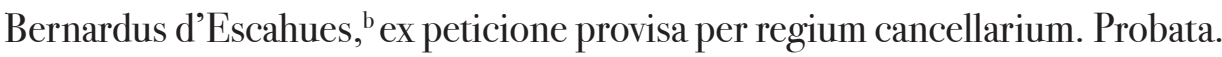

(a) causa: $\operatorname{cog}$ causa (b) exp. mandato.

$\operatorname{miI} \sim \pi$

I372, gener.

Pagament de 720 sous barcelonesos al físic Bartomeu de Tresbens, de la casa del rei, per la seva quitació ordinària d'octubre de 1372 a gener de 1373.

ACA, RP, MR, vol. 2477 , f. 58 r.

Ítem, done a maestre Berthomeu de Tresbens, metge de física de casa del senyor rey, los quals li eren deguts ab albarà d'escrivà de ració per rahó de sa quitació, és a ssaber, del primer dia del mes d'octobre de l'any proppassat tro per tot lo derrer dia del mes de janer present, segons que en lo dit albarà se conté, que cobre - DCCXX sous barcelonesos.

[Marg. esq.: ]Albarà.

$\min 2 \pi$

I372, abril I6. Saragossa.

El rei Pere atorga un salconduit a Bartomeu de Tresbens, Guilhem Durandi Joan Durand, per desplaçar-se amb les seves mercaderies i sojornar de manera lliure i segura sota protecció reial per tots els territoris de la Corona d'Aragó, estenent-lo a tots els seus fautors, procuradors, negociants i servidors. El document també inclou el dret de penyorar i de prendre represàlies, i obliga els beneficiaris a pagar lleudes, peatges i altres drets. El càstig previst per a qui no respecti aquest salconduit és de mil morabatins d'or.

ACA, C, reg. 922 , f. $75^{\mathrm{r}-\mathrm{v}}$.

Nos Petrus, et cetera, ut vos, Bartholomeus de Tribusbonis, fisicus domus nostre, et Guillelmus Durandi ac Iohannes Durandi, filius vestri, dicti Guillelmi, mercatoris civitatis Apamiarum, regni Ffrancie et comitatus Fuxi, cum vestris factoribus, negociatoribus, procuratoribus et famulis, per nostre proteccionis presidium ab omni iactura valeatis salubrius preservari, et quia plus timeri 
solet quod specialiter iniungitur quam quod generaliter imperatur, tenore presentis carte nostre recipimus atque ponimus vos, predictos Bartholomeum, Guillelmum et Iohannem, ac factores, negociatores, procuratores et famulos vestros sub nostra proteccione, custodia et comanda, ita quod in terra nostra ubilibet possitis negociari et marcari atque morari cum rebus seu mercibus vestris salve, pariter et secure et occasione marche, represalie seu pignorandi licencie per nos vel officiales nostros concesse vel concedende adversus subditos regis Ffrancie et comitis Ffuxi sumi. Ipsa concessio sit vel fiat ratione debitorum que nobis aut subditis nostris debentur et debebuntur per dictos regem et comitem seu eorum subditos vel alia ratione quacumque aut alia culpa, crimine vel debitis alienis: non possitis in persona vel bonis in terra nostra capi, detineri, arrestari, marchari, pignorari seu alio quomodolibet impediri, nisi in ipsis fueritis principaliter aut fideiussorio nomine obligati, nec etiam in hiis casibus nisi prius in vobis fatica inventa fuerit de directo et inquantum foris et racio fieri hoc permittant nec aliis vobis nec eis malum vel dapnum aliquid in personis vel bonis fieri seu inferri aut iniuriam offensam seu violenciam aliquatenus irrogari. Nos enim huius serie vos et ipsos cum omnibus bonis, rebus et mercimoniis vel mercibus vestris et societatis vestre guidamus et assecuramus ab omnibus marcharum, represaliarum et pignacionum licenciis per nos aut officiales nostros quoscumque, ut predicitur, concessis et concedendis, ac de gratia speciali extrahimus ac liberos facimus, continuos et immunes, dum tamen vos seu factores vestri nullam salvateriam pendente huiusmodi guidatico faciatis. Nullus ergo confidens de nostri gracia vel favore audeat seu presumat vos vel factores, negociatores, procuratores et famulos vestros aut res merces seu bona vestra palam vel occulte in terra nostra capere, detinere, marchare vel aliquatenus impedire contra hanc nostram proteccionem, vobis tamen solvente lezdas, pedagia et alia iura debita ac etiam consueta. Mandantes per presentem inclito et magnifico infanti Iohanni, primogenito nostro, carissimo duci Gerunde et comiti Cervere regnorumque et terrarum nostrarum gubernatori generali eiusque vicesgerentibus, vicariis, baiulis, iusticiis, merinis supraiunctariis, calmedinis ceterisque officialibus et subditis nostris presentibus et futuris dictorum officialium locatenentibus quatenus protectionem, custodiam et comandam ac guidaticum nostra huiusmodi firma habeant et observent ac faciant ab aliis inviolabiliter observari et non contraveniant nec aliquem contravenire permittant aliqua ratione. Nulli ergo hominum liceat hanc protectionem nostram et guidaticum infringere vel ei ausu ductus temerario contrahire, quicumque autem contravenire presumpserit iram et indignacionem nostram ac penam mille morabatinorum auri nostro erario applicandorum se noviter absque remedio aliquo incurrisse, damno illato primittus et plenarie restituto, addicentes quod vos, predicti Bartholomeus, Gullielmus et Iohannes et quilibet ex predictis, eisdem casibus et in eisdem causis in penam presentis proteccionis censeamini incidisse in qua quicumque alii vos prenominatos seu aliquem ex predictis factoribus, negociatoribus, procuratoribus et famulis vestris, ut prefertur, offendentes inciderent ipso facto, ut utrinque equalitas observetur. In cuius rei testimonium presentem cartam nostram fieri et sigillo nostro pendenti iussimus comuniri. Data Cesarauguste, sextadecima die aprilis anno a Nativitate Domini millesimo trecentesimo septuagesimo secundo regnique nostri tricesimo septimo. Bernardus de Val.

Guillelmus Calderoni, mandato regio facto per Bernardum de Bonastre, secretarium. Dominus rex habuit eam pro visa. Bernardus de Bonastre. 
$m 13 \%$

I372, juny 20. Cervera.

Els paers i el consell de la vila de Cervera negocien un contracte amb el físic i astròleg Bartomeu de Tresbens per tal que aquest s'hi traslladi a exercir la medicina. Després de diversos encontres, les negociacions fracassen.

ACSG, Llibre de Consells (Cervera, I372), 220-3o-TI-8, ff. 34r-v, 36r-37v i 38v-39r.

[ff. 34r-v] Die veneris, intitulata XXX ${ }^{\mathrm{a}}$ die mensis iulii, anno a Nativitate Domini Mo CCCLXX secundo, foren en l'obrador d'En Guillem Lambart, a Conseyll, los pahers, conseyllers ${ }^{29} \mathrm{e}$ prohòmens dejús scrits: Ramon Part, Guillem Lambart, Pere Taylada, pahers. | | *Berenguer de Cardona, ${ }^{*}$ Dalmau Zacirera, Bernat Desvall, Bernat Laurador, * Guillem Puyalt, *Pericó des Castell, | *Arnau de Riudoveylles, Andreu Cavalera, Pere Bugaresa, Ffrancesch des Archs, *Berenguer de Mecina, Berenguer Serra, | Pere de Muntpahó, Ramon Vergós, Ramon de Rochafort, Anthoni Vilar, Pere Gilabert, *Ramon Dan, | Jacme Ferrer, notari, Bernat de Caneles, savi [en dret], *Barthomeu Ripoll, Ramon Martí.

E fo proposat en Conseyll per los dits pahers que azí en la vila no ha degun metge ne axí matex hinc ha persona qui lige e tinge escoles. E ara azí ha vengut I metge, a qui dien En Berenguer Zabater, qui volenter se aturarà zí e legirà de gramàtica e de lògica, si la vila li vol dar cascun any XV libres e fer-li franquesa de quèstia, d'ost, de cavalcada e de obra, e que li don aquesta pensió a cert temps, él aturarà volenter. E com los pahers de azò sens conseyll no ajan poder, per zo pregaren al Conseyll que acordàs què farien sobre aquest feit.

E axí matex fo proposat per los dits pahers que los síndichs que són a Barcelona han feit saber que maestre Bathomeu de Tresbens és a Barcelona, e si hom li dave pensió suficient que venrie azí estar, per què pregaren al Conseyll que acort què faran sobre aquest feit.

E sobre azò lo Conseyll acordà que, com sie necesitat, per obs dels inffants, aver maestre dea lògica e de gramàticab, e axí matex de haver metge, que si maestre Berenguer vol azí aturar a X libres de pensió, que la li donen; si no, que li donen XV libres e que li fazen la ffranquesa damunt dita, la qual pensió [f. 34v] li donen a-quell temps que ab ell se poran havenir. E prometeren haver per ferm zo que ells faran, dona[n]t-los poder de obligar los béns de la universitat e lursc , e de azò los feren sindicat.

[ff. $36 \mathrm{r}-\mathrm{v}]$

Dicmenge, a XXVI del mes de setembre, foren en l'obrador de la scrivania de mi, Pere Tous, notari, a Conseyll, los pahers, conseyllers e prohòmens dejús scrits:

Guillem Lambart, Pere Taylada, [pahers]. | | Arnau de Mecina, ${ }^{*}$ Berenguer de Cardona, Guillem d’Agramuntell, ${ }^{*}$ Arnau de Riudoveylles, * Berenguer d’Escales, Jacme Moxó, Pere Castelet,

29. A la llista següent marcats amb el signe 9, 'con', i aquí amb asterisc. Aquest signe fa referència als prohoms assistents que ostentaven el càrrec de consellers. Agraïm a Max Turull aquesta apreciació. 
Ffrancesch de Comambla, ${ }^{*}$ Guillem Puyalt, Pere de Canet, Barthomeu de Muntbrió, | Berenguer Gilabert, Bernat des Canós, Ramon de Rochafort, ${ }^{\mathrm{d}}$ * Barthomeu Ripoll, ${ }^{*}$ Ramon Dan, ${ }^{*}$ Miquell Cardona, *Pere de Fontanet, Berenguer de Vergós, Bernat de Menresa, Ramon Martí, *Felip Ferrer, I *Berenguer Presó.

E fo proposat en Conseyll per los dits pahers que ells han reebuda una letra dels prohòmens que són a Barcelona continent en acabament, que havien tractat ab maestre Barthomeu de IIIbens que se'n vingués estar azí en la vila a praticar de sa art de medecina, enperò que a la fi avie a costar L libres, les quals volie que li fosen dades per XV anys o de sa vida, e encara franquesa de quèstia e de comú, de ost e de cavalcada e de obres de murs e de vals e de tota altra cosa, e encara, que li donen alberch franch. E, axí matex, que tractament era estat feit entre ells e En Berenguer Moxó que la vila que relexàs al dit Berenguer Moxó tot zo que degués tro al dia de huy, e de azí avant que contribuhís axí com I altri singular, segons que azò e altres cosses en la dita letra e en una altra per lo feit del dit En Berenguer Moxó tramesa largament se conté. On, con los pahers dels [f. $36 \mathrm{v}$ ] dits feits no puxen ne vuyllen res fer sens conseyll, pregaren al Conseyll que sobre los dits feits acordasen què porien fer.

$[\ldots]$

Sobre lo feit de maestre Barthomeu de IIIesbens fo acordat que, com aquesta sie una de les notables viles de Cathalunya e estige fort mal sen un sollemniall metge e, segons fama, lo dit maestre Barthomeu sie bon metge e gran astròlech, per zo, lo Conseyll acordà que sie respost als prohòmens nostres qui són a Barcelona que ells pratiquen ab lo dit maestre Barthomeu que la universitat, entre totes cosses, li aja a dar L libres e no més, e fer franch de quèstia, de host, de cavalcada [e] de obres de murs e de valls. E en cas que àls no s’i puxe fer, que de pensió L libres e loguer d alberch ${ }^{\mathrm{e}}$, franch. E aquesta pensió li donen a $\mathrm{X}$ anys e si àls no poden, a XV anys.

Dix En Berenguer de Cardona e N’Arnau de Riudoveylles que si maestre Pere d'Isovals podien haver axí prestament com aquest, que sie agut e no aquest, si ve, e maestre, si no poden haver que aquest.

Dix En Guillem Puyalt que d'aquestes coses sie hagut major conseyll.

[f. $37^{\mathrm{r}-\mathrm{v}}$ ]

Dicmenge, a III del mes de octobre, foren en la sala de la paheria, a Conseyll, los pahers, conseyllers ${ }^{30}$ e prohòmens dejús scrits:

Guillem Lambart, Pere Taylada, [pahers]. | | Arnau de Mecina, ${ }^{\mathrm{f}}$ Berenguer de Cardona, Berenguer Gilabert, Berenguer de Vergós, Bernat de Caneles, Pere de Vergós, Jacme Moxó, Ffrancesch de Tàrega, | *Anthoni Tolrrà, * Guillem Puyalt, Bernat de Manresa, Guillem d'Agramuntell, Ramon de Rama, *Pere des Castell, *Arnau de Riudoveylles, Pere de Vergós, * Miquell Cardona, I

*Barthomeu Ripoll, ${ }^{*}$ Berenguer Presó, ${ }^{*}$ Felip Ferrer, ${ }^{*}$ Ffrancesch de Menresa, Nicolau de Vergós, Berenguer Serra, Guillem Tolrrà, * Barthomeu Amaldes, *Pere de Fontanet, | Bernat Candom, Berenguer Lobet, Guillem Màger, *Berenguer d'Escales, *Pere des Prat, Pere Tordera, Ffrancesch d’Enbrú, Pere Brunet.

$[\ldots]$

30. A la llista següent marcats amb el signe 9 , 'con', i aquí amb asterisc. 
Ítem, fo proposat en conseyll que, com en lo Conseyll pasat fos estada lesta una letra tramesa per los dits síndichs en què feit metien si volien dar pensió a maestre Barthomeu L libres cascun any, e fos acordat que li fos donada, segons que en l'altre Conseyll se conté, enperò, com hi agués alguna diversistat, los pahers scriviren a maestre Pere d'Isovals, lo qual ha respost que si.l volien sperar un any, que és apereyllat de venir, segons que largament en Ia letra per ell tramesa se conté. Per què, com [en] aquell Conseyll hi agués alguna diversitat, pla[f. 37v]gés al Conseyll que hi acordàs sàviament.

Al feit de maestre Barthomeu fo acordat per lo Conseyll que En Berenguer de Vergós, qui deu anar a Barcelona ense[m]ps ab En Pere Dan, tracte si-l porà haver a III o IIII anys, o a V, e axí matex si-l poran haver per menys quantitat. E que de azò que·n faran que·n scrive, e lo Conseyll que s'acort.

$[\ldots]$

[f. $3^{8 \mathrm{v}}$ ]

Disapte a XXII del mes de octobre del dit any foren en la església dels prehicadós de la dita vila, a Conseyll, los pahers, conseyllers ${ }^{3 \mathrm{I}}$ e prohòmens dejús scrits:

Ramon Pere, Pere Taylada, [pahers]. I| Berenguer de Cardona, Berenguer Gilabert, Pere de Vergós, Jacme de Berga, Barthomeu de Morenyà, Pere de Muntpahó, Andreu de Loberola, Guillem de Vatllòria, Jacme Ferrer, notari, Pere de Canet, notari, | Pere Castelet, Pere des Prat, Matheu Desvall, Ramon de Rochafort, Bernat Ju[n]yent, maestre Ramon Sanz, Guillem d’Agramuntell, Matheu de N’Arz, Ramon Desvilar, Guillem Zelòlim, | Bernat de Foix, Pere des Castell, Matheu Bonjoch, Pere Brunit, Andreu Tolrrà, Anthoni Tolrrà, Pere Pereylló, Arnau de Mecina, Barthomeu de Robió, | Pere Ripoll, Guillem Major, Arnau des Forn, Ramon Vidall, Pere d’Òdena, Pere Miró, Bernat Oller, Stheve Candell, Guillem Delà.

E fon lesta en Conseyll una letra d'En Berenguer de Vergós, qui era síndich a Barcelona, e axí matex uns capítolls feits per maestre Barthomeu de IIIbens, en la qual letra era contengut que En Pere Martí metria a conexenza dels prohòmens que.l Conseyll hi à elets, ab què En Jacme Conesa e En Bertran de Pinós, o la I d'ells, hi fasen ab ells ensenps. E axí matex del metge, que si li volen dar la pensió, zo és, $\mathrm{C}$ florins cascun any a $X$ anys, que ell venrà, com pus largament en les dites letres se conté. Per què pregaren al Conseyll que acordàs què farien sobre aquest feit. [...]

[f. 39 r]

Quant al feit de maestre Barthomeu de Tresbens, fo acordat que.ls pahers, ab alguns prohòmens, mitig[u]en e adoben los capítols e puys que li sie dada pensió L libres a $X$ anys. Aquest feit de maestre Barthomeu digueren En Matheu Bonjoch, Anthoni Tolrrà, Bernat de Foix, Andreu Tolrrà, Pere Brunet, Barthomeu Ripoll, Pere des Castell, Jacme Ferrer, que no consentien, com deman masa gran pensió e a masa gran temps, majorment com no hinc aja bastant conseyll.

(a) exp. scoles (b) lògica e de gramática s. l. (c) e lurs s. l. (d) exp. Pere Ripoll (e) exp. li donen (f) exp. Barthomeu. 
$\min m$

I373, gener $3^{\text {I. }}$

El tresorer del rei, Pere Desvalls, paga a mestre Bartomeu de Tresbens, metge de física del monarca, els 240 sous barcelonesos que aquest li ha concedit com a gràcia.

ACA, RP, MR, vol. 364, f. rogv.

Ítem, done a maestre Barthomeu de Tresbéns, mege de ffísica de casa del senyor rey, ab albarà d'escrivà de ració scrit en Barcelona derrer dia del mes de jener proppassat de l'any present MCCCLXXIII, los quals lo senyor rey graciosament li manà donar, segons que en lo dit albarà se conté, que cobre - CCXL sous barcelonesos.

[Marg. esq.:] Albarà.

$\min 2 \pi$

I373, abril.

Pagament de 540 sous barcelonesos al físic Bartomeu de Tresbens, de la casa del rei, per la seva quitació ordinària de febrer de 1373 a abril de 1373.

ACA, RP, MR, vol. 2477, f. 8Iv.

Ítem, done a maestre Berthomeu de Tresbens, metge de física de casa del senyor rey, los quals li eren deguts ab albarà d'escrivà de ració per raó de sa quitació, és a ssaber, del primer dia del dit mes de fabrer tro per tot lo derrer dia del mes d'abril present, segons que en lo dit albarà se conté, que cobre. - DXL sous barcelonesos.

[Marg. esq.:] Albarà.

$\min$

I373, abril.

El tresorer del rei, Pere Desvalls, paga a mestre Bartomeu de Tresbens, metge de física del rei, „6o sous barcelonesos pel vestit de l'any 1373.

ACA, RP, MR, vol. 364, f. I33v.

[f. I33r] Ítem, done a les persones dejús scrites de cavall e de peu de casa del senyor rey, ab sengles albarans d'escrivà de ració scrits en Barcelona primer dia del mes de abril de l'any present MCCCLXXIII, les quantitats davall specifficades, les quals lus eren degudes per rahó de lur vestit del dit any $[\ldots]$

[f. I33v] Ítem, a maestre Barthomeu de Tresbens, metge de física. - CCCLX sous barcelonesos. 
$\min 17 \pi$

I373, juliol.

Pagament de 540 sous barcelonesos al físic Bartomeu de Tresbens, de la casa del rei, per la seva quitació ordinària de maig de 1373 a juliol de 1373.

ACA, RP, MR, vol. 2478 , f. 27 r.

Ítem, done a maestre Bertholomeu de Tresbens, metge de física de casa del dit senyor, los quals li eren deguts ab albarà d'escrivà de ració per raó de sa quitació, és a ssaber del primer dia del mes de maig proppassat tro per tot lo derrer dia del mes de juliol present, segons que $\cdot n$ lo dit albarà se conté, que cobre. - DXL sous barcelonesos.

$\operatorname{mid} m$

I373, setembre.

El dispenser, Pere Blan, paga 330 sous barcelonesos a Bartomeu de Tresbens, metge de física de casa del rei, per la seva quitació ordinària.

ACA, RP, MR, vol. $5^{87}$, f. $5^{2 \mathrm{v}}$.

Ítem, done $\mathrm{a} \cdot \mathrm{N}$ Berthomeu de Tresbens, metge de físicha de casa del senyor rey, ab albarà d'escrivà de ració scrit en València a XXVII de setembre del dit any, los quals lo dit senyor li manà donar en acorriment de sa quitació, per ço com lo dit senyor lo féu venir per afers seus de la ciutat de Barcelona açí a la ciutat de València, segons que·s conté en lo dit albarà, lo qual cobre - CCCXXX sous barcelonesos.

[Marg. esq.:] Albarà.

$\sin \pi$

I373, setembre I. València.

Linfant Joan escriu al seu pare, el rei Pere el Cerimoniós, per tal que li envï el metge Bartomeu de Tresbens, perquè necessita els seus serveis.

ACA, C, reg. I739, f. 42 v.

Molt alt etcètera. Sàpia la vostra magnificència que jo he fort necessari maestre Bertholomeu de Tresbens, metge vostre, per necessitat de ma persona. Per què us suplich que li vullats donar licència e li manets que de continent vingue a mi, e com abans poré lo us trametré. Man-me, senyor etcètera. Scrit en València, primer dia de setembre de l’any MCCCLXXIII. Primogenitus.

Senyor, lo vostre humil primogènit etcètera. 
Dominus dux mandavit Bernardo d'Escahues. Probata.

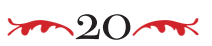

I373, setembre I. València.

Linfant Joan ordena al seu armer Joan Gener que porti al metge Bartomeu de Tresbens unes cartes en les quals li ordena que es presenti davant ell. Ordena també que l’acompanyi ique li avanci els diners de les despeses que el viatge de Barcelona a València comportarà al metge.

ACA, C, reg. I739, f. $43^{\mathrm{v}}$.

Lo primogènit etcètera.

Nós escrivim al senyor rey supplicant-li que do licència a maestre Bertholomeu de Tresbens, metge seu, de venir a nós e que li man que tantost a nós vingue, e axí mateix ne escrivim al dit maestre Bertholomeu, segons que per los translats de les letres que nós enviam als dits senyor rey e maestre dins la present intercluses veurets. Les quals letres e altra de la duquessa tramet al dit maestre ligades ab aquesta que a vós trametem volem e us manam que vos presentets als damunt dits senyor e maestre e façats ab ells que en tota manera lo dit maestre Bertholomeu vingue tantost a nós, e vingue-sse’n ab vós, e vós, en cars que lo dit maestre ho deman, bestraet-li a sa despesa de cavalcadures tro sia ab nós. E en cars que vós de continent no puixats venir a nós, ço que no creem, donat al dit maestre per a messió ço que us parrà, si lo dit maestre, segons dit és, ho demanarà. Car nós vos farem pagar tot ço que bestret li haurets. E en cars que vós siats partit de Barcelona, escrivent a qualque amich vostre, trametet-li les dites letres e faça per vós tot lo damunt dit que vós haurets a fer. [Scrita] et signata ut supra. [=Data en València, sots nostre segell secret, primer dia de setembre, l’any MCCCLXXIII. Primogenitus]. Al feel armer nostre En Johan Janer.

Dominus dux mandavit Bernardo d'Escahues. Probata.

$\min 2 \mathrm{~m}$

I373, setembre 4. València.

Linfant Joan demana a Bartomeu de Tresbens, metge del rei, que acudeixi a la seva presència amb llibres d'astrologia i de física.

ACA, C, reg. I739, f. 44r.

Ed.: Rubió I9o8-I92I: I, 25O, núm. 264; Roca I923: 264.

A Bartomeu de Tresbens.

Lo primogènit etcètera.

Com ja per altra letra nostra vos hajam escrit que per necessitat de nostra persona vos hajam mester e us pregàssem e manàssem que, tots afers a parts posats, vinguéssets a nós, segons que 
en la dita letra, que dada fo en València, primer dia del mes e any devall escrits, pus largament és contengut; on, com nós de certa sciència vullam que per la dita nostra necessitat vingats a nós, per ço volem e us manam que, vinent de continent a nós, aportets ab vós tots los libres vostres e a vós necessaris, així en astrologia com en física, e que per res no triguets, si·ns desijats servir ne complaure. Dada en València, sots nostre segell secret, a IIII dies de setembre de l'any MCCCLXXIII. Primogenitus.

Al feel nostre maestre Bertholomeu de Tresbens, metge en medicina del senyor rey.

Dominus dux mandavit, Bernardo d'Escahues.

$\operatorname{mon} 22 \pi$

I373, setembre 4. València.

Linfant Joan recorda que ha sol.licitat a la seva presència Bartomeu de Tresbens, metge del rei, per tal que li porti uns llibres, i ordena al seu uixer que llogui una atzembla per al metge i que vagin tots dos a la seva presència.

ACA, C, reg. I739, f. 44r.

Lo primogènit etcètera.

Nós escrivim a maestre Bertholomeu de Tresbens que vingue a nós, segons que ja li havem escrit e de una letra que nós li havem feta ara trametre transcrit dins la present entreclús, per tal que vejats ço que li fem a saber, pregants e manants-vos que, per a portar los libres de què nós li escrivim, li loguets atzembla e li façats la messió segons que ja us havem escrit. Ítem, vos fem saber que mossèn Ffortuny Péreç Calmello és mort e del seu ofici havem proveït a mossèn Johan de Gurrea e a vós, de ofici de uxer. Per ço us pregam e manam que, vista la present, tots afers a part posats, vingats a nós ab lo dit maestre Berthomeu ensemps, e açò per res no haja falla. Data e signata ut supra. [=Data en València, sots nostre segell secret, a IIII dies de setembre, l'any M CCC LXXIII. Primogenitus]. Al feel uxer d'armes nostre En Johan Janer.

Idem [=Dominus dux mandavit Bernardo d'Escahues]. Probata.

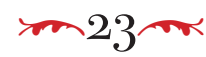

I373, octubre 2I. València.

L'infant Joan s'adreça a Pere Blan, el seu conseller i dispenser, per informar-lo que Huguet de Cardona, conseller i dispenser de la infanta Mata d'Armanyac, ha avançat, per ordre seva, 24 florins d'or a diversos personatges, i entre altres al físic del rei Bartomeu de Tresbens.

ACA, C, reg. I762, f. I53v.

Infans Iohanne, et cetera, fideli consiliario et expensori nostro Petro Blan, salutem et graciam. 
Cum ffidelis noster Huguetus de Cardona, consiliarius et expensor inclite infantisse Mathe, consortis nostre carissime, bistraxerit et exsolverit nostro mandato viginti quatuor florenos auri aragonensis, videlicet magistro Bartholomeo de Tresbens, fisico dicti domini regis, decem florenos, et Abraham Barbut, iudeo, septem florenos, quosquidem magistrum Bartholomeum et Abraham de civitate Barchinone venire fecimus ad nos, et Bernardo de Podio, aventurerio, pro quodam suo mulo in quo dictus iudeus equitavit, residuos septem florenos. Ideo vobis dicimus et mandamus quatenus de peccunia curie nostre que est vel erit penes vos, tribuatis et exsolvatis Iohanni Michelis, de officio expensorie dicte nostre consortis, recipienti nomine dicti Hugueti dictos viginti quatuor florenos auri. Et, facta solucione, recuperetis a dicto Iohanne presente loco apoche et mandati. Data Valencie, XXI a die octobris anno a Nativitate Domini $\mathrm{M}^{\circ} \mathrm{CCC}^{\circ} \mathrm{LXXIII}{ }^{\circ}$. Berengarius de Ponte.

Dominus dux mandavit Berengario Sarta. Probata.

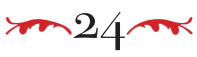

I373, novembre.

El dispenser de l'infant Joan, Pere Blan, paga so florins d'or a Bartomeu de Tresbens, metge de física de casa del duc, per donació graciosa que aquest darrer li ha fet.

ACA, RP, MR, vol. 587, f. 66r.

Ítem, done a mestre Berthomeu de IIIbens, metge de físicha de casa del senyor duch, ab albarà d'escrivà de ració scrit en València a XIX d'octubre de l'any present MCCCLXXX, los quals lo dit senyor li manà donar graciosament, segons que.s conté en lo dit albarà, lo qual cobre - XXX florins d'or.

[Marg. esq.:] Albarà.

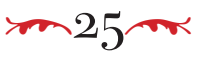

I373, desembre.

El dispenser de l'infant Joan, Pere Blan, paga 495 sous barcelonesos a Bartomeu de Tresbens, metge de fisica de casa del rei, per la quitació de quatre bèsties corresponent a dos mesos i quinze dies que estigué a la cort.

ACA, RP, MR, vol. 587, f. 86r.

Ítem, done a mestre Berthomeu de Tresbens, metge de física de casa del dit senyor, ab albarà d'escrivà de ració scrit lo dit die, per raó de ça quitació de IIII bèsties, és a ssaber, del primer dia de setembre proppassat, que fo reebut de casa, tro per tot lo dit derrer die de noembre, que són IIII meses, dels quals ha stat tan solament ab la cort II meses, XV dies, dels quals li són abatuts per acorriment que li fo fet a raó de CCCXXX sous, segons que.s conté en lo dit albarà, lo qual cobre CCCCXCV sous barcelonesos.

[Marg. esq.:] Albarà. 
$m 26 \pi$

I374, abril 23. València.

L'infant Joan atorga llicència a Bartomeu de Tresbens, físic del rei i seu, perquè pugui exportar 150 quintars de figues del regne de València i mana expressament a tots els oficials que no hi posin cap impediment

ACA, C, reg. I65I, ff. 88v-89r.

Infant etcètera. Als amat e feels lo portantveus per nós en regne de València, batlle general e tots e sengles altres officials e sotmeses del dit senyor rey e nostres dins lo dit regne constituïts e dels dits officials lochtinents als quals les presents pervendran e les dejús scrites coses se pertanguen, salut e dilecció. Com nós, a supplicació del fel físich del senyor rey e nostre maestre Bartholomeu de Tresbens humilment a nós feta, hajam atorgat e donada licència al dit maestre Bartholomeu que, franchament e sens pena alcuna, puixe traure o fer traure del dit regne e portar e fer portar a les parts que·s volrà dins la terra del senyor rey e nostra CL quintars de figues, per ço a vós e a cascú de vós dehim e manam expressament e de certa sciència que, observan les dites concessió e licència nostres, lexets o permetats al dit maestre Bartholomeu, o altri per ell en nom seu, traure del dit regne e portar o fer portar a les parts dessusdites la quantitat de figues damunt declarada, qualssevol inibicions, ordenacions e provisions, axí reyals com locals, en contrari fetes, les quals quant a açò revocam e volem per revocades ésser haüdes, en alcuna cosa no contrastants. Data en València, sots nostre segell secret, a XXIII dies de octobre de l'any de la Nativitat de nostre Senyor MCCCLXXIV. Primogenitus.

Dominus dux misit eam signatam expediendam. Probata.

$m 27 m$

I374, maig I3. València.

L'infant Joan trasllada al governador de Rosselló i Cerdanya la petició de Bartomeu de Tresbens de permetre a un enviat seu de passar a França, garantint-li un trajecte segur, per buscar llibres i altres propietats pertanyents al metge i retornar-los-hi.

ACA, C, reg. I717, f. 96 r.

Infans Iohannes, et cetera, nobili et dilecto gerenti vices nostras in Rossilione et Ceritania ceterisque officialibus regiis sive nostris parcium earundem, salutem et dileccionem. Cum presencium exhibitor vadat pro nunc ad partes Ffrancie pro certis negociis fidelis domestici nostri Bartholomei de Tribusbonis, magistri in medicina, debeatque reducere ipsi magistro libros et quedam alia bona sua, propterea, supplicante nobis pro hiis Bartholomeo prefato, vobis et cuilibet vestrum mandamus quatenus dictum exhibitorem ire et redire cum libris et aliis antedictis libere permittatis, providendo nec minus eidem, si expediens fuerit, de securo transitu et conductu. Data Valentie, XIII ${ }^{\text {a }}$ die madii anno a Nativitate Domini millesimo CCC ${ }^{\circ}$ LXX $^{\circ}$ quarto. Bernardus, cancellarius. 
Dominus dux mandavit mihi, Petro de Tarrega.

$m 28 \pi$

I374, octubre 3I. Sant Mateu del Maestrat.

Linfant Joan envia el físic reial Bartomeu de Tresbens al seu pare, el rei Pere el Cerimoniós, per tal que li expliqui directament unes prediccions que li ha fet sobre l'un i l'altre i sobre els regnes.

ACA, C, reg. I742, f. 7v.

Ed.: Rubió I9o8-I92I: 2, I75, núm. I87; Roca 1923: 275.

Molt alt e molt excel·lent príncep e senyor, pare e senyor a mi molt car. Sàpia la vostra magnificència que lo feel físich vostre e meu, maestre Bartholomeu de Tresbens, m’à dites algunes paraules tocants vós e mi e tots los regnes vostres, de les quals ell havia parlat ab vós en Barcelona, e aquelles trobà per sciència d'estrologia. Et com jo no me entena, segons que vós, senyor, sabets, en aquelles e vós les sabets, per ço tramet-vos lo dit físich, lo qual vos plàcia oyr e haver acort en ço que us plaurà e tremetre-me’n resposta per ell matex ço que-n determenarets. Man-me, senyor, la vostra senyoria ço que li plàcia. Scrita en la vila de Sent Matheu, vigília de Tots Sants de l'any MCCCLXXIIII. Primogenitus.

Senyor, lo vostre humil primogènit, besan vostres peus e mans, se comana en vostra gràcia e benedicció.

Idem [=Dominus dux mandavit Bernardo d'Escahues]. Probata.

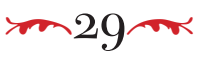

I374, desembre 2. Cervera.

El rei Pere el Cerimoniós mana al lloctinent del mestre racional que atengui el que li diran Bartomeu de Tresbens i Dalmau Sesplanes, astròleg, que han estat cridats a Cervera per ell.

ACA, C, reg. 1357 , f. 2 r.

Lo rey.

Nós manam venir aquí per alguns afers nostres lo feel de casa nostra maestre Bartomeu de IIIbens, los quals han a fer aquí, a ell e Dalmau Sesplanes, de casa nostra. Per què us deïm e manam que a açò que.ls dits maestre Barthomeu e Dalmau Planes vos diran sobre.ls dits affers, de nostra part, creegats axí com si nós ${ }^{b}$ vos ho deÿem e.ls endrecets sobre aquells, e d'açò $\cdot n s$ farets plaer e servey. Dada a Cervera, sots nostre segell secret, a II dies de deembre de l'any MCCCLXXIIII. Rex Petrus.

Bernardo de Colle, locumtenenti magistri rationalis. Dominus rex misit signatam. Probata

(a) aquí s. l. (b) nós s. l. 
m $30 \%$

I374, desembre 8. Cervera.

El rei Pere el Cerimoniós ordena al tresorer que pagui g lliures barceloneses que són degudes al seu fisic Bartomeu de Tresbens.

ACA, C, reg. I357, f. Iov.

Lo rey.

Trasorer: com nós trametam aquí per alguns affers nostres maestre Barthomeu de Tresbens, metge de físicha de casa nostra, manam-vos que li paguets tot ço que li resta a pagar d'un albarà de IX lliures que ell vos darà, e açò per res no mudets. Dada a Cervera, sots nostre segell secret, a VIII dies de deembre de l'any MCCCLXXIIII. Rex Petrus.

Idem [=Dominus rex misit signatam]. Probata.

$\min$

I374, desembre Io.

La duquessa Mata d'Armanyac sol.licita al rei Pere que li envï Bartomeu de Tresbens, per tal que l'atengui d'un refredat amb febre.

ACA, C, reg. I8II, f. 59v.

Ed.: Tuixans I926.

Molt alt e molt excel·lent príncep e senyor, pare e senyor meu molt car. Sàpie la vostra molt gran altea que jo he haüt cadarn ab un poch d'escalfament. Per què plàcia a vós, molt alt senyor, de licenciar e manar a maestre Barthomeu de Tresbens que, vista la present, vingue a mi, e tendré-us-ho, senyor, en gràcia e mercè. Man-me, molt alt senyor, la vostra molt gran altea, ço que li plàcie, car jo, axí com a humil e devota filla vostra, me offir apparellada de complir tots vostres manaments. Scrita en Leyda, a X de deembre, l'any de MCCCLXXIIII. Berengarius, prothonotarius.

Dirigitur domino regi.

Senyor, la vostra humil etcètera.

Domina ducissa mandavit Berengario Sarta. 
$3^{2} \pi$

I374, desembre Io. Lleida.

La duquessa Mata d'Armanyac reclama la presència de Bartomeu de Tresbens per tal que la visiti per unesfebres que pateix.

ACA, C, reg. I809, f. I05r.

La duquessa.

Com nós hajam haüt e hajam cadarn ab un poch d'escalfament, per ço us pregam e a vós dehim e manam que vista la present vingats a nós, lexats tots affers. Certifficants-vos que nós escrivim al senyor rey, pare e senyor nostre molt car, que us don licència de venir. Per què falla ne tarda alguna no hage la dita vostra partida. Data en Leyda, a X de deembre de l'any MCCCLXXIIII. Berengarius, prothonotarius.

Dirigitur magistro Bartholomeo de Tribusbonis.

Idem [=Domina ducissa mandavit Berengario Sarta]. Probata.

$m 33 m$

I374, desembre II. Lleida.

La duquessa Mata d'Armanyac escriu al seu marit, el duc Joan d'Aragó, informant-lo del seu bon estat de salut i explicant-li que Bartomeu de Tresbens encara no ha acudit a atendre-la del seu refredat. També l'informa que no ha pogut lliurar unes cartes que li havia encomanat per l'accident d'una criada i per la malaltia que ha patit.

ACA, C, reg. I8II, f. 6or.

Ed.: Tuixans 1926 .

Molt car senyor, una letra havem reeebuda de la vostra senyoria, de la qual havem haüt lo millor pler que haver poguéssem, per ço com havem entès lo bon stament de la vostra persona, plàçia a nostro senyor Déus que.l vos prest per molts anys e bons. De nós sapiats, senyor, que disapta proppassat haguem un poch d'escalfament, però, merçè de nostre senyor Déus, mellorada som, e entenem, Déus volent, que àls no sie. Ítem, senyor, trametem a mestre Barthomeu de Tresbens que vingue a nós, però encara no és vengut. Per ço, senyor, vos en certificam que no entenats ne creegats que àls sie. Les letres, senyor, que trametíets a ffrare Guillem d'Abella e a mossèn Johan de Gorrea no les los havem dades, ans les havem squinçades, e açò, senyor, per tal com vós volets que romangam açí. No us meravellets, senyor, com nós no us scrivim, car madona Besatriu s’à trenchat lo peu, e nós que jahíem. Manats-nos, senyor, ço que us plàçia. Scrita en Leyda, diluns, ora tarda, a XI de deembre en l'any de MCCCLXXIIII. Berengarius, prothonotarius.

Domino duci dirigitur.

Humil companyona vostra, la duquessa. 
Domina ducissa mandavit Berengario Sarta. Probata.

$34 \pi$

I374, desembre I2. Lleida.

La duquessa Mata d'Armanyac reclama a mestre Bartomeu de Tresbens que acudeixi a Lleida per tractar-la d'una febre, de la qual pateix des de fa un dies i ha empitjorat.

ACA, C, reg. I809, ff. Io5r-v.

Ed.: Tuixans 1926.

La duquessa.

Sapiats que disapte proppassat haguem una pocha de febre e ara n'avem més avant e sentim-nos molt piyor. Per què us pregam affectuosament que, si jamés entenets res a fer a honor e a pler nostre, vingats a nós vista la present e lexats tots e qualsevol affers. E açò per res no hage falla, si a nós entenets jamés servir ne complaure. Data en Leyda, a XII de deembre en l'any de MCCCLXXIIII. Berengarius, prothonotarius.

Dirigitur magistro Bartholomeo de Tribusbonis, medico.

Domina ducissa mandavit Berengario Sarta. Probata.

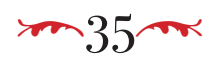

I375, març 8. Saragossa.

L'infant Joan s'adreça a Perpinyà Blan, el seu conseller i dispenser, informant-lo que el seu metge Bartomeu de Tresbens ha retornat a la cort un rossí afollat que ha lliurat a Pere Selvi, capellà $i$ almoiner seu, com consta en un albarà del 5 de març del cavallerís Miguel Pérez del Roy, i, en conseqüència ordena que se li compensi el rossí amb 500 sous barcelonesos, segons el costum.

ACA, C, reg. 1764 , f. $36 \mathrm{v}$.

Magistri Bartholomeo de Tribusbonis.

Infans Iohannes, et cetera, ffideli consiliario et expensori nostro Perpiniano Blan, salutem et graciam. Cum fidelis noster magister Bartholomeus de Tribusbonis, medicus noster, quendam roncinum suum de pilo castaneo et balzanum duobus pedibus restituerit nostre curie pro affollato ipsumque fideli capellano nostro Petro Çelvi, regenti officium elemosinarii domus nostre, tradiderit, ut per albaranum fidelis cavallericii nostri Micha[e]lis Petri del Roy, scriptum Cesarauguste quinta die marcii anno subscripto, quod in nostri cancellaria fuit exhibitum et inhibi pro cautela nostre curie laceratum constitit plene nobis, et propterea quingentos solidos barchinonenses pro emenda dicti roncini iuxta stilum curie nostre per vos providimus sibi tradi. Pro tanto, vobis dicimus et expresse mandamus quatenus de peccunia curie nostre que est vel erit 
penes vos tribuatis et exsolvatis dicto magistro Bartholomeo vel cui voluerit loco sui iamdictam peccunie quantitatem. Et, facta solucione, recuperetis ab eo presentem cum apocha de soluto. Data Cesarauguste, VIII a die marcii anno a Nativitate Domini $\mathrm{M}^{\circ} \mathrm{CCC}^{\circ} \mathrm{LXX}^{\circ} \mathrm{V}^{\circ}$. Iohannes de Ponte.

Dominus dux mandavit mihi, Bertrando de Pinós. Probata.

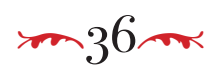

I375, abril II. Saragossa.

Linfant Joan encarrega a Bartomeu de Tresbens una comissió per controlar tots aquells que exerceixin la professió mèdica en els territoris de la Corona d'Aragó-sense haver estat formats en un estudi general-, i exposa les consideracions i les disposicions sobre l'establiment d'un examen mèdic amb aquest propòsit. També pretén controlar i regular la qualitat dels productes venuts en les apotecaries, on es cometen abusos molt sovint. Per a tals afers es podran convocar oficials diversos i notaris per a la certificació corresponent. Ordena que ningú pugui obstaculitzar aquesta comissió.

ACA, C, reg. 1682, ff. 9Iv-92v.

Comissio super omnes medicos medicine tangentes.

Nos, infans Iohannes, et cetera, quoniam certum est nobis quam plurimos homines seu etiam mulieres diversarum legum et sectarum ausu temerario indigne propter sui impericiam artem medicine, phisice et cirurgie praticam exequentes in regno Aragonis et alibi, quod in periculum animarum suarum non modicum convertitur et totius rei publice detrimentum, maxime cum corpora humana que liberam extimationem non recipiunt propter pestifferas ordinationes medicorum imperitorum corrumpuntur et perent, et multos esse apothecarios falsas, indebitas et corruptas medicinas observantes et usu ac modo illicito ministrantes lexativas, imo verius potiones mortiferas, absque peritorum medicorum licentia et ordinationem gentibus vendentes, libello etiam quid pro quo cognominato utentes in receptis unum pro reliquo ponentes, et ita et alias varias deceptiones in detrimentum christicolarum nostrorumque subiectorum et eorum scandalum comittentes que omnia non modicum nostrum animum non sine causa agravarunt, idcirco zelo iustitie moti et propter rei publice utilitatem et alia que nos movent et movere debent pro equitate iustitie ad custodiam subiectorum et ad obviandum etiam maliciis eorum qui ausu temerario talia comittunt et de eis iustitia exequatur, confidentes de sufficientia et legalitate vestri, fidelis nostri phisici Bartholomei de Tribusbonis, in artibus et medicina profesoris, tenore presentis dicimus, comittimus et mandamus vobis, in virtute iuramenti per vos nobis prestiti, quatenus quoscumque homines seu mulieres cuiusque legis aut secte fuerint arte medicine utentes phisice aut cirurgie modo quovis, profesoribus tamen aut licenciatis in generalibus studiis dumtaxat exemptis, inveneritis in regnis Aragonum et Valencie ac aliis terris dicti domini regis et nostris, examine rigoroso et sufficienti comprobetis aliquo vobis adiuncto, si vobis videatur expediens, medico et aliquibus officialibus prefati domini regis et nostris aut proceribus loci in quo fueritis convocatis. Et si interesse voluerint vobiscum quibus volueritis, liceat comprobare uno publico notario ad hoc adibito et portarii aut sagiones ad nostri mandatum quos volueritis convocare convocent et de comparendo coram vobis compellant. Apotecarios etiam et materialia in eorum tentoriis comprobetis uno adiuncto iurato eiusdem officii et procere seu almudacaffo civitatis vel 
loci in quo predicta facietis. Quibus examinacione et comprobacione finitis et tentoriis perquisitis, volumus ut malas medicinas igni comburetis et quos idoneos et sufficientes inveneritis ex parte nostra medicos ad predictam praticam exercendam licencietis. Circa eam et debent in eadem et fideliter operando, ab ipsis iuramentum recipiatis. Si vero imperitos quosdam inveneritis eos, ad studium, si tales fuerint qui ad hoc intendant, remittatis, alios vero vagabundos et deceptores a predictis pratica, exerciciis et actibus repellatis inibendo eisdem sub penis quibus vobis videbitur imponendis, sive pecuniariis sive corporalibus usque ad effussionem sanguinis inclusive, exceptis dumtaxat membrorum emutilatione et morte, quas duas penas ultimo positas nobis reservamus, puniendas alias vobis committimus et vestro arbitrio imponendas. Volumus etiam quod, cum vel sive alicuius alterius iudicis ordinarii seu officialis predicti domini regis et nostrorum mandato aut subrogatione possitis per partes, tamen requisitis, ubi alie partes non convenerint, salaria et labores medicorum taxare et vulneratos disuspitare et omnia alia et singula accidentia et que proveniencia sunt medicinis et infirmis comprobare. Et si necesse fuerit, aliquem idoneum profesorem tamen ac sufficientem licenciatum in medicina in qualibet provincia ad premissa substituere et subrogare. Et ad hec alia observanda vobis et per vos substitutis sive subrogatis mandamus omnibus iuratis, consulibus, paciariis et proceribus, calmedinis, merinis, vicariis, baiulis et omnibus aliis officialibus dicti domini regis et nostris seu eorum locatenentibus presentibus et futuris quatenus vobis pareant, obediant et ad finalem execucionem producere non cessent et in nullo premissorum vos conturbent neque conturbare permittant, sub penis mille morabatinorum auri et indignatione prefati domini regis et nostra. In quibus siquidem penis, si quibus proderit, volumus nobis terciam partem pertinere, quam nobis nunc sicut tunc et econtra adiudicamus, et adiudicatam concedimus reliquas duas partes erario domini regis et nostro presentis serie applicamus. Nos enim vobis super premissis omnibus et singulis vices nostras plenarie conmutamus per presentes. In cuius rei testimonium hanc fieri et sigillo nostro pendenti iussimus communire. Data Cesarauguste, XI ${ }^{\mathrm{a}}$ die aprilis anno a Nativitate Domini MCCCLXX quinto. Primogenitus.

Dominus dux misit eam signatam et expediendam. Probata.

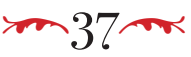

I375, abril 28. Saragossa.

L'infant Joan mana al seu metge Bartomeu de Tresbens que, la comissió que li va fer per al control de metges, cirurgians, apotecaris i altres practicants de la medicina, ha de deixar-la en suspens si no la confirma el rei per escrit.

ACA, C, reg. I625, ff. I89r-v.

Infans Iohannes et cetera, ffideli medico nostro Bartholomeo de Tribusbonis, salutem et gratiam. Cum de et super contentum in quadam comissionis carta per nos vobis facta tam super examinacione medicorum, cirurgicorum, apothecariorum et aliorum artem medicam ${ }^{\mathrm{a}}$ exercencium quam eciam aliorum in dicta carta expressatorum ex iusticia et probabilibus causis in nostri conspectu proponitis, volumus quod eisdem seu aliquo ipsorum non utamini, quinimo intromittere nullatenus vos curetis de contentis specificatis in dicta comissionis carta modo aliquo sive causa, si predicta dictus dominus rex non aprobaverit cum eius littera de sui certa scientia. Et expresse contrarium vero faciendi potestatem omnimodam vobis presenti serie abdicamus volentes per 
eandem et dictis medicis, cirurgicis, apothecariis et aliis in dicta comissionis carta comprehensis mandantes, sibique expressius inhibentes, quod nobis in et super premissis minime pareant nec mandata vostra in hiis compleant seu faciant, donec per dictum dominum regem cum eius carta seu littera aliter fuerit ordinatum. Data Cesarauguste, XXVIII a die aprilis anno a Nativitate Domini millesimo $\mathrm{CCC}^{\circ} \mathrm{LXX}^{\mathrm{o}}$ quinto. Primogenitus.

Dominus dux misit eam signatam expediendam. Probata.

(a) scripsi: medicam<smiles>C[Se][As]</smiles>

I375, abril 28. Saragossa.

Linfant Joan reclama als seus oficials que, si troben Pere Draper, servidor de Bartomeu de Tresbens, amb el qual vivia en la seva residència a Barcelona, i que havia estat acusat pel físic d'haver-li robat joies i llibres de negocis segellats, li retornin les pertinences robades al seu propietari, que es farà càrrec de les despeses, i apliquin al lladre un càstig exemplar.

ACA, C, reg. I625, f. I92r.

Infans Iohannes et cetera, universis et singulis officialibus dicti domini regis et nostris vel eorum locatenentibus, salutem et dilectionem. Cum fidelis de domo nostra Bartholomeus de Tribusbonis, in artibus et medicina professor, apud Barchinona de nostris licencia et permissu intenderet dirigere gestus suos et cum aliquibus rebus et iocalibus seu eciam libris negociorum suorum clausis et sigillatis quendam qui cum eo morabatur, Petrum Draper vulgariter nuncupatum, miserit apud dictam civitatem, ubi suum favet domicilium, et licet ab eodem magistro Bartholomeo dicto Petro cum eo comitanti esset expresse creditum in mandatis ut recto tramitte ad dictam civitatem accederet, ipse tamen Petrus suis neclectis contra voluntatem dicti magistri Bartholemei veniens a recto tramite deviavit sinistram viam, pocius quam dextram eligendo, cum rebus per ipsum Bartholomeum dicto Petro tramissis furtum committendo. Ideo vobis et unicuique vestrum dicimus et mandamus quatenus, si dictum Petrum infra iurisdicciones vobis seu alicui vestrum comissas reperire poteritis, capiatis et captum eum distringatis ad redendum dicto magistro supradicto quecumque bona que reperitis per eundem Bartholemeum dicto Petro esse comissa cum expensis et dampnis per dictum Bartholemeum factis et sustentis et de eodem Petro iusticiam taliter faciatis, quod ei ad penam et ceteris similia temptare volentibus pertranseat in exemplum. Taliter vos habendo in hiis et circa premissa, ne dictus conquerens coram nobis hac de causa racione in iusticie in vobis reperte de cetero venire habeat cum querela. Data Cesarauguste, XXVIII a aprilis anno a Nativitate Domini $\mathrm{M}^{\circ} \mathrm{CCC}{ }^{\circ} \mathrm{LXX}^{\circ} \mathrm{V}^{\circ}$. Iohannes de Ponte.

Petrus de Besanta mandato domini ducis facto per regium cancellarium. Probata. 